Artigo

\title{
As Cooperativas de Catadores e o Lixo: Fragmentos de um Desamparo Estrutural
}

The Collectors of Cooperative and Trash: Fragments af a Structural Helplessness

Los Colectores de Cooperativas y Basura: Fragmentos de un Impotencia Estructural

Vinícius Ferreira Baptista ${ }^{1}$

\footnotetext{
${ }^{1}$ Filiação institucional. Administrador. Mestre pelo Programa de Pós-Graduação em Políticas Públicas e Formação Humana da Universidade do Estado do Rio de Janeiro. Pesquisador do Centro de Ciências Exatas e Tecnologia da Universidade Federal do Estado do Rio de Janeiro, Rio de janeiro, RJ, Brasil.

Correspondência:

E-mail: viniciusferbap2007@hotmail.com
}

Resumo O objetivo deste trabalho é o de identificar e relativizar situações enfrentadas pelas cooperativas de catadores de materiais recicláveis, a partir das visões dos gestores das mesmas. Primeiramente, apresentamos uma breve conjuntura das organizações coletivas que atuam com a coleta seletiva. Em seguida, destacamos a metodologia destinada à coleta e analise dos dados. Posteriormente, apresentamos as situações enfrentadas pelas cooperativas, ao passo em que estabelecemos a análise dos dados coletados e destacamos interpretações sobre o tema. Situamos que as cooperativas trazem perspectivas e limites, em paralelo com as políticas públicas, de se mudar ou de se adaptar a coleta seletiva em qualquer empreendimento, não somente no Município do Rio de janeiro, onde a pesquisa de campo foi empreendida. Enfatizamos que temos as Políticas, Atores e Instituições. O desafio é o de organizar pessoas, interesses, vozes, problemas e soluções.

Palavras-chaves: Cooperativas de Catadores; Políticas Públicas; Resíduos Sólidos; Coleta Seletiva; Desamparo. 


\begin{abstract}
The objective of this work is to identify and contextualize situations faced by cooperatives of collectors of recyclable materials from the views of their managers. First, we present a brief scenario of collective organizations who work with the selective collection. Then we highlight the methodology for the collection and analysis of data. Subsequently, we present the situations faced by cooperatives, while we set the data analysis and highlight interpretations on the topic. After, we situate that cooperatives bring prospects and limits, in parallel with public policies, to change or to adapt to selective collection in any endeavor, not only in the city of Rio de Janeiro, where the fieldwork was undertaken. We emphasize that we have Policies, Institutions and Actors. The challenge is to organize people, interests, voices, problems and solutions.
\end{abstract}

Keywords: Recycling Cooperatives; Public Policy; Solid Waste; Selective Collection; Structural Helplessness.

Resumen El objetivo de este trabajo es identificar y relativizar las situaciones que enfrentan las cooperativas de recolectores de materiales reciclables a partir de los puntos de vista de los gestores. En primer lugar, se presenta un breve panorama de las organizaciones de colectivos que trabajan con la recogida selectiva. A continuación, se resalta la metodología para la recopilación y análisis de datos. Posteriormente, se presentan las situaciones que enfrentan las cooperativas, mientras ponemos el análisis de los datos y las interpretaciones más destacadas sobre el tema. Por fin, se sitúa que las cooperativas traer perspectivas y límites, en paralelo con las políticas públicas, de cambiar o adaptarse a la recogida selectiva en cualquier empresa, no sólo en la ciudad de Rio de Janeiro, donde se realizó el trabajo de campo. Hacemos hincapié en que las Políticas, Instituciones y Actores. El desafío consiste en organizar a la gente, los intereses, las voces, los problemas y las soluciones.

Palabras Clave: Cooperativas de Reciclaje; Políticas Públicas; La Recogida de Residuos Sólidos; Desamparo Estructural. 


\section{Introdução}

O Plano Nacional de Resíduos Sólidos (BRASIL, 2012) traz algumas considerações sobre os catadores de materiais recicláveis. A atividade de catação no Brasil, segundo o Plano, apresenta limitações no que toca a organização dos mesmos frente ao sistema de coleta seletiva. De acordo com o Plano:

- Há hoje entre 400 e 600 mil catadores de materiais recicláveis no Brasil;

- Ao menos 1.100 organizações coletivas de catadores estão em funcionamento em todo o país;

- Entre 40 e 60 mil catadores participam de alguma organização coletiva, isto representa apenas $10 \%$ da população total de catadores;

- $27 \%$ dos municípios declararam ao IBGE ter conhecimento da atuação de catadores nas unidades de destinação final dos resíduos;

- $50 \%$ dos municípios declararam ao IBGE ter conhecimento da atuação de catadores em suas áreas urbanas;

- Cerca de $60 \%$ das organizações coletivas e dos catadores estão nos níveis mais baixos de eficiência;

- A renda média dos catadores, aproximada a partir de estudos parciais, não atinge o salário mínimo, alcançando entre $\mathrm{R} \$ 420,00$ e $\mathrm{R} \$ 520,00$;

- A faixa de instrução mais observada entre os catadores vai da $5^{\underline{a}}$ a $8^{\underline{a}}$ séries.

Em linhas gerais, estes dados indicam um sério problema público envolto à questão dos catadores, cujos contornos compreendem aspectos conjunturais socioeconômicos, político-institucionais e ambientais. A magnitude dessa questão social, por muito tempo ignorada e situada como "estado de coisas", ou seja, uma situação que se arrasta por um tempo longo, incomodando e gerando insatisfação, chegando a mobilizar as autoridades governamentais, mas que não se constitui em item da agenda governamental, perfazendo a não-decisão, ou seja, um tema que por contrariar interesses, enfrentam obstáculos e não são inclusos (RUA, 2009: 70).

Esta questão tornou-se visível, devido não somente ao próprio problema público e si, mas também à organização política e institucional dos atores envolvidos que, agora constituídos, empreenderam esforços no sentido de publicizar e tornar "público" um problema até então visto como consequência de desemprego, baixa qualificação profissional etc. 
O que estes dados do Plano Nacional de Resíduos Sólidos (BRASIL, 2012: 25) indicam preliminarmente é que os catadores estão em um cenário em que as cooperativas se apresentam como meios à mudança e melhores oportunidades. Por outro lado, as cooperativas apresentam limitações. Há um número significativo de pessoas inseridas em sistemas cooperativistas voltados à coleta seletiva (entre 400 e 600 mil em aproximadamente 1.100 organizações coletivas). Por outro lado, o Poder Público pouco reconhece tais pessoas e organizações. Essas organizações, em sua maioria, apresentam níveis baixos de eficiência e distribuição de renda. Não há como desvincular essa baixa produtividade e eficiência aos níveis de instrução dos catadores (a faixa mais elevada se situa no ensino fundamental). Por conta disso, surgem na tentativa de enfrentamento a esse problema público, políticas públicas voltadas para a inclusão social dos catadores, sustentabilidade econômica de sua atividade e desenho de políticas eficazes voltadas aos mesmos.

O Plano Nacional de Resíduos Sólidos situa que foram destinados mais de $\mathrm{R} \$ 280$ milhões em ações voltadas aos catadores de materiais recicláveis entre 2003 e 2010, assim como uma política de Pagamento por Serviços Ambientais Urbanos - PSAU, com a previsão de remuneração dos catadores pelos serviços ambientais resultantes de sua atividade e da criação do Programa Pró-Catador, que articula e integra as ações do Governo Federal voltadas ao apoio e fomento à organização produtiva dos catadores. Por fim, o Plano destaca as diretrizes gerais para a inserção da questão dos catadores no Plano:

- Promover o fortalecimento das cooperativas e associações de catadores, buscando elevá-las ao nível mais alto de eficiência;

- Promover a criação de novas cooperativas e associações e regularização daquelas já existentes, com vistas a reforçar os vínculos de trabalho, incluir socialmente e formalizar os catadores que atuam de forma isolada;

- Promover a articulação em rede das cooperativas e associações de catadores;

- Criar mecanismos de identificação e certificação de cooperativas, para que não haja falsas cooperativas de catadores beneficiadas com recursos públicos;

- Fortalecer iniciativas de integração e articulação de políticas e ações federais direcionadas para o catador, tais como o programa pró-catador e a proposta de pagamentos por serviços ambientais urbanos;

- Estipular metas para a inclusão social de catadores e garantir que as políticas públicas forneçam alternativas de emprego e renda aos catadores que não puderem exercer sua atividade após a extinção dos lixões, prevista para 2014; 
- Estipular metas com o objetivo de inclusão social e garantia de emprego digno para até 600 mil catadores, até o ano de 2014;

- As metas focadas na garantia de emprego devem estabelecer o piso de um salário mínimo para a remuneração do catador. O piso de remuneração também deve levar em conta as diretrizes do Plano Brasil Sem Miséria, que prevê renda per capita mínima de 70 reais por membro da família;

- Estimular a participação de catadores nas ações de educação ambiental e sensibilização porta-a-porta para a separação de resíduos na fonte geradora, mediante a sua adequada capacitação e remuneração;

- Demandar dos municípios a atualização de sistemas de informação sobre a situação dos resíduos municipais e gestão compartilhada dos resíduos;

- Estabelecer metas e critérios para que os municípios incluam os catadores na gestão municipal de resíduos sólidos;

- Garantir o acesso dos catadores aos resíduos sólidos urbanos coletados seletivamente;

- Promover a integração dos catadores de materiais recicláveis aos sistemas de logística reversa.

As diretrizes acima, em consonância com os objetivos, estratégias e instrumentos da PNRS visam criar projetos e estruturar condições para a melhoria socioeconômica e fortalecimento político-institucional das cooperativas de catadores de materiais recicláveis.

Desta forma, as cooperativas estão focalizadas pela gestão pública e pelas políticas públicas. Antes renegados, os catadores de materiais recicláveis foram elevados a postos de atores estratégicos na formulação de planos para a gestão dos resíduos sólidos urbanos, notadamente após a sanção da Política Nacional de Resíduos Sólidos Urbanos (PNRS), Lei no. 12.305/2010.

\section{Metodologia}

Foi empreendida uma pesquisa de campo com o objetivo de relativizar situações enfrentadas pelas cooperativas de catadores de materiais recicláveis, mas, sobretudo, a de identificar as perspectivas e limites das políticas públicas voltadas à coleta seletiva, além das positividades e negatividades das cooperativas e oportunidades e ameaças enfrentadas pelas mesmas.

De duas listas obtidas junto à Companhia Municipal de Limpeza Urbana (COMLURB) e à Secretaria de Estado do Ambiente do Rio de Janeiro (SEA), foram selecionadas três cooperativas de catadores de catadores pertencentes às listas. 
O critério de escolha foi essencialmente pela investigação de cooperativas associadas à Federação Brasileira das Cooperativas de Materiais Recicláveis (FEBRACOM) e que já tivessem participado de chamadas públicas com o Governo do Estado do Rio de Janeiro e/ou a Prefeitura da Cidade do Rio de Janeiro. Dos três empreendimentos pesquisados, uma está em processo de legalização; as outras duas são cooperativas, com estatutos formalizados.

Foram aplicados questionários pautados pela estrutura dicotômica e de múltipla escolha e seguido um roteiro de entrevista semiaberta, onde inclusive, foi necessária algumas vezes a reformulação de perguntas e explicações sobre determinamos itens. As entrevistas realizadas se deram nos galpões das cooperativas, onde, inclusive, aplicou-se a técnica da observação. Antes das entrevistas foi perguntada a possibilidade de gravação de voz, o que foi permitido. Contudo, para não expor os(as) entrevistados(as), a partir deste ponto, todos serão tratados como "Gestor da Cooperativa", identificados como do empreendimento " $A$ ", " $B$ " $e$ " $C$ ".

Como toda política pública é um processo social e que possui materialidade histórica, a análise das cooperativas foi realizada com base na Análise do Discurso dos gestores de cooperativas, que teve como objetivo de pesquisa analisar em que perspectivas a relação social de poder no plano discursivo se constrói. O pesquisador se coloca como agente participante de uma determinada ordem, contribuindo para a construção de uma articulação entre linguagem e sociedade (ROCHA; DEUSDARÁ, 2005: 321). Um dos limites desta análise e, consequentemente, desta pesquisa, é que este método de investigação é "uma interpretação do discurso produzido por outros" (VERGARA, 2010: 20). Por conta disso, há de se considerar a subjetividade do pesquisador.

\section{Resultados e Discussão}

Podemos estabelecer que cada entrevista tem um conteúdo e um discurso com certo caráter. O Gestor A pautou-se mais pelo seu conhecimento técnico, advertindo falhas e pontos positivos sobre a engrenagem da coleta seletiva. Em outro prisma, o Gestor B situou sua fala mais na mobilização política e a obrigação de organização em paralelo à necessidade de aproximação com o Estado. Já em uma terceira visão, o Gestor C pondera o sistema político, o seu distanciamento com atores importantes do processo, a invisibilidade de atores, a incoerência das políticas e propostas de solução.

Foi percebida no semblante dos gestores a tentativa de não se trazer um discurso acabado. Na maioria das pesquisas esta é uma tentativa comum utilizada por entrevistados, notadamente quando se fazem sempre as mesmas perguntas. Neste caso, o entrevistado está "treinado" o suficiente para "responder" sua pergunta. Por outro lado, nas conversas com os gestores, foi percebida a oportunidade de se revelar as necessidades das cooperativas, 
trazerem os problemas, mas também as coisas boas e as mudanças ocorridas na coleta seletiva. Os gestores foram conscientes de citar que não foi a primeira vez que foram entrevistados

Como situado por um dos gestores, "trabalho bom muita gente vai visitar [...]. Vem aqui também na cooperativa e.... também essa não é primeira entrevista que eu estou dando não, já veio muitas pessoas da Uerj também aqui" (GESTOR DA COOPERATIVA B, 2013). É claro que quando a cria é bonita, seus pais aparecem. Mas e quando a cria é feia? Como situado por outro gestor, "porque aqui vem gente todo dia fotografar, filmar, entrevistar, e não sei o quê não sei o que lá, mas a situação continua igual. Você entende?" (GESTOR DA COOPERATIVA C, 2013).

Por que a situação não muda? O que se está pesquisando nas cooperativas de catadores? $E$, quando há pesquisa, onde estão as propostas? $E$, se há propostas, por que não vem sendo consideradas? Há a negação por problemas públicos? É esta a materialização da não decisão, situada por Rua (2009)?

O desamparo estrutural em que as cooperativas de catadores de materiais recicláveis estão passando já foi percebido há muito tempo pela mídia, pelo governo e pela sociedade. Se existem políticas públicas voltadas ao tema, é porque esse problema já foi identificado. Contudo, este problema pode ter sido identificado e uma política ter sido criada, mas ainda não ser uma issue, ou seja, uma questão política, por isso tem-se políticas simbólicas e políticas sem sentido que não solucionam os problemas.

As políticas não são condições suficientes para a resolução de problemas públicos. As políticas são condições necessárias a todo um ordenamento que envolve a sua pactuação. Este é o processo por meio do qual as políticas públicas são pensadas, elaboradas, percebidas, implementadas, executadas e avaliadas conjuntamente pelos atores políticos, governamentais e não governamentais, com o apoio de Instituições e espaços de negociação política abertos e estimulados à participação. Destacamos o termo "percebidas" pelo fato de que as políticas públicas são altamente subjetivas e padecem do processo de intersubjetividade dos atores, ou seja, ainda que sejam pensadas pelo maior número de atores políticos conjuntamente, corre-se o risco de que as mesmas não sejam percebidas da mesma forma

Necessita-se, desta forma, o reconhecimento das conexões envoltas à política pública e principalmente a consideração da mesma como meio às mudanças transformadoras da realidade social, além de Instituições, ou seja, normas conhecidas por todos e que induzem a participação política. Ao mesmo tempo, as condições de igualdade na construção das políticas precisam ser asseguradas nos espaços de negociação. Não há como criar políticas públicas efetivas se os atores não possuem canais abertos e públicos para o diálogo e negociação. 
Não obstante, necessita-se mudar o olhar sobre as cooperativas. As cooperativas estão em situação de desamparo estrutural, mas não são atores desamparados estruturalmente. Há uma diferença básica entre estar em uma situação e possuir essa característica. Estar em uma situação de desamparo significa que há fatores, variáveis, atores e demais possibilidades que afetam a estruturação em que se encontra. Possuir essa característica é outra questão que aponta para uma permanência dessa característica.

As cooperativas não precisam ser vistas como "coitadinhas". Elas precisam de auxílio? Sim, elas precisam. As cooperativas estão encontradas em situação de desamparo estrutural. Estrutural pelo sentido de estar desamparada social, econômica, infraestrutura, política e cultural. Entre as cinco cooperativas pesquisadas, nenhuma estava amparada em todas as condições acima apontadas - em um ou outro ponto estava desamparada.

As cooperativas não querem dinheiro. Elas querem desenvolver o seu trabalho. Todos os gestores foram unânimes: não querem favores; eles querem dignidade. O primeiro situa que "cooperativa mesmo pra viver, como a gente vive, tem que ser com nossos pés. Entendeu? [...] Tudo é nossos pés. Não é projeto, não é ninguém que deu nada pra gente não." (GESTOR DA COOPERATIVA A, 2013). O segundo aponta que "nós não queremos esmola, nós não precisamos de esmola, nós queremos dignidade e sermos tratados como tais. Por isso que nós estamos fazendo o nosso trabalhinho aqui" (GESTOR DA COOPERATIVA C, 2013).

O gestor da cooperativa C é bem taxativo na questão da "esmola social", em que são adotadas medidas paliativas e não medidas transformadoras da realidade social. Estas medidas são válidas em determinado contexto, mas que não podem se transformar em vícios, mas serem indutoras de transformações. $O$ gestor contextualiza que

O ser humano precisa um salário bom e oportunidade de trabalho, ninguém precisa de bolsa pra sobreviver, isso daí não é questão social, isso não leva a nada. Você, é ao contrário, você afunda um pouquinho mais e acomoda um pouquinho mais eles nessa situação. Que o dia dele receber bolsa-família, eles faltam ao trabalho. Então parece até um contrassenso. Essas coisas são boas, mas não devem ser assim.... Devem ser canalizadas, tem que remunerar e dar dignidade quando você trabalha, quando você faz a parte que a sociedade precisa que alguém faça. (GESTOR DA COOPERATIVA C, 2013).

As cooperativas clamam pela dignidade do seu trabalho. Os catadores trabalham com aquilo que é desvalorizado e descartado pelas empresas, pelos consumidores e pela sociedade em geral - o lixo, e são capazes de visualizar e agregar valor a esses materiais. As cooperativas criam valor sobre aquilo que é considerado sem valor. 
Por conta disso, o trabalho nas cooperativas precisa e deve ser valorizado e difundido, sendo também amplamente amparado. De modo a trazer a mudança de mentalidade, dentro e fora da cooperativa, como situada pelo próprio gestor, ao destacar que "só que nós, brasileiros, somos o país do coitadinho. Ainda essa mentalidade é nojenta, a gente tem que mudar" e que "tem que haver uma mentalidade, a gente não precisa ajudar os outros, tem que dar dignidade de trabalho" (GESTOR DA COOPERATIVA C, 2013). O papel do governo é essencial à essa mudança, amparando as cooperativas e dando suporte, não no sentido de assistencialismo, mas de estruturação a fim de emancipação social, como apontado pelo gestor $\mathrm{C}$, quando aponta que "não é querer ficar ajudando, ficar isso... não, não, não, a gente tem que ter dignidade. Nós não somos pessoas que precisam de tratamento diferenciado, especial. Bom, me dê dignidade, me dê trabalho, e eu vou sobreviver a essa situação toda. Isso é importante" (GESTOR DA COOPERATIVA C, 2013).

A mudança qualitativa sobre o "lixo" foi essencial ao fortalecimento das cooperativas. O lixo não é mais adequado. Segundo um dos gestores, quando perguntado sobre essa denominação lixo, o mesmo diz que "tem até briga. Agora é reciclável". E quando perguntado sobre o início dessa mudança, destaca que "porque lixo era vergonha né? Hoje em dia você fala 'eu trabalho na reciclagem' e todo mundo se orgulha. Eu me orgulho. Quando eu entrei mesmo no trabalho eu tinha até vergonha - 'eu trabalho no lixo'". Posteriormente, com o avanço da conscientização e com a mudança dessa qualidade pejorativa para positiva, esse mesmo gestor, atualmente, diz que "agora não. Agora eu tenho prazer em falar 'eu trabalho na reciclagem', meio ambiente... Tá sendo um sucesso hoje em dia né? E também pra natureza também e pra tudo" (GESTOR DA COOPERATIVA A, 2013).

Outro gestor também concorda ao situar a recente mudança qualitativa no trabalho dos catadores:

Os catadores... É uma profissão que surgiu de agora, muito recente e já tá regulamentada, como profissão, então isso demonstra, denota uma preocupação para que isso possa caminhar. Que a gente tá fazendo um trabalho, um trabalho mais ou menos difícil, não gosto de dizer isso, de trabalho sujo. Não é um trabalho sujo. Que essa conotação "suja" pareceria ilegal, não sei o que... Não, é um trabalho em cima de resíduos, então é um trabalho "sujo" nesse sentido. (GESTOR DA COOPERATIVA C, 2013).

Outro gestor é ainda mais taxativo destacando a mudança qualitativa na percepção dos resíduos sólidos. Este gestor vê a influência direta do expresidente da República Luís Inácio "Lula" da Silva nessa mudança, notadamente a partir de 2010. Segundo este gestor, foi Lula quem "vem dar a honra pra coleta seletiva [...]. O Lula foi quem apoiou os catadores. É que falou em Brasília que o catador era uma pessoa trabalhadora igual a um funcionário do banco, igual a pessoas que fizessem qualquer serviço, entendeu?". Ainda segundo este gestor "foi onde a gente veio se dar o valor, porque a gente pensava que a gente não 
tinha valor. Mas graças a Deus, hoje em dia a gente tem valor, devido ao reconhecimento. E foi aonde eu criei meus filhos, foi através da reciclagem do lixo" (GESTOR DA COOPERATIVA B, 2013).

Aqui se percebe a clara diferença entre o valor do lixo e o valor pelo lixo. 0 valor de lixo está na capacidade que este material tem de trazer recursos àqueles que trabalham com o resíduo. O valor pelo lixo está na capacidade que o resíduo teve em mudar a realidade daqueles que trabalham com o lixo.

Por outro lado, todos destacam o início difícil da coleta seletiva, como o gestor da cooperativa A, ao apontar que "eu fui trabalhar porque estava necessitada, desempregada. Quando eu comecei, eu comecei a trabalhar na Usina Verde como catadora na esteira mesmo" (GESTOR DA COOPERATIVA A, 2013). O outro gestor situa que "antigamente não existia reciclagem, existia a gente chegava no lixão pegava todo o material e juntava tudo e levava pra pesar e vender de qualquer jeito entendeu? A gente queria ir pra casa com dinheiro, pra gente alimentar nossos filhos" (GESTOR DA COOPERATIVA B, 2013).

Esse início da coleta seletiva vem culminar com a desigualdade social e a necessidade como indutores de mobilização dessas pessoas. A necessidade fez a ocasião do envolvimento com o resíduo. Posteriormente, passou-se a desenvolver este trabalho.

Essa questão da desigualdade social é reforçada pelo entendimento de outro gestor, situando que "o analfabeto e o pobrinho, bem pobrinho, o máximo que ele consegue vislumbrar é uma semana, 2, 3 dias, então o espírito de imediatismo, é ali, você não pode fazer a longo prazo. Porque a fome é imediata, daí a coisa é imediata". Por conta disso é que "então você que tá ali, precisa sobreviver naquele momento" (GESTOR DA COOPERATIVA C, 2013).

Essa mudança de mentalidade precisa ser construída, mas a fome é imediata, as necessidades são imediatas, as desigualdades são imediatas. São exigidas assim, políticas públicas imediatas, pois existem pessoas que sobrevivem do lixo em péssimas condições. Para saber em quais condições essas pessoas trabalham, basta ir a uma cooperativa. Lá se verão condições mínimas de trabalho e segurança insuficientes ao desenvolvimento pleno das atividades. Seria interessante a visita dos policymakers ao locus que pretende intervir. Seria interessante estreitar a distância existente entre os gabinetes daqueles que fazem as políticas públicas daqueles que serão público-alvo das mesmas. São necessárias ações que visem o fortalecimento das cooperativas e de seus cooperados no intuito de estruturação da ação coletiva.

Em outra perspectiva, há um posicionamento entre os gestores de que as cooperativas são empreendimentos temporários e não uma escolha de vida. Um dos gestores situa que "quando as pessoas saem, elas ficam um bom tempo, é porque elas encontraram coisa melhor. Pra eles foram melhor. A menina mesmo que trabalhou pra gente como catadora, ela foi trabalhar na prefeitura. Não é 
melhor? Com certeza, entendeu?" (GESTOR DA COOPERATIVA A, 2013). O outro gestor destaca que "isso aqui não é uma meta de vida, é um trampolim pra você começar a desenvolver" (GESTOR DA COOPERATIVA C, 2013). Outro gestor também aponta que "olha, sabe que largaram o serviço lá e voltaram pra cooperativa? [...] Aqui pra trazer gente pra cá não precisa não porque eles já sabem da cooperativa, já sabem que essa cooperativa aqui é deles. Eles estão passando lá e corre. Quando eles estão passando algum aperto eles correm pra cooperativa" (GESTOR DA COOPERATIVA B, 2013). Os gestores também destacaram no questionário que procuram desenvolver ações para manter os cooperados, mas esbarram na falta de recursos; os mesmos entendem esses projetos como essenciais à cultura da partilha e solidariedade

Tal conjuntura configuraria um contrassenso. Forma-se um grupo à custa de muito diálogo e interação; depois de algum tempo começam a surgir os primeiros recursos, os primeiros clientes, os primeiros frutos; posteriormente a situação inicia a melhorar; em seguida, os primeiros associados deixam o grupo e este começa a desintegrar. Como manter o propósito inicial do empreendimento? Como manter as relações de confiança e reciprocidade quando os membros não são mais os mesmos?

Interessante situar que, uma vez cooperativado, sempre cooperativado, pois "essa porta aqui é aberta, é igual à Igreja. A Igreja não está aberta para os seus fiéis? Então isso aqui é aberto para os nossos fiéis. Para os nossos catadores" (GESTOR DA COOPERATIVA B, 2013). Por isso que "tem pessoas que saem, vão ver alguma coisa, quer outro trabalho. Daqui a pouco se não tiver bem lá, volta de novo. E as portas estão sempre abertas" (GESTOR DA COOPERATIVA A, 2013).

Se um dos cooperados consegue um emprego de carteira assinada, isso é visto como positivo e não como negativo pelos gestores de cooperativas; pelo contrário, isso é reforçado. As cooperativas são vistas como passageiras, ou seja, como oportunidades de crescimento, uma chance de se ter a possibilidade de mudar a própria vida.

Então, isso a gente fica feliz e contente, porque demos uma chance, demos uma oportunidade. Muitas vezes as pessoas ficam se lamentando, "ah, não tenho sorte, ah, não sei o quê, não arrumo emprego". Eu não sei, deve ter algum probleminha, porque aqui quem quiser trabalhar, pode trabalhar e vai ganhar bem. Depende do esforço pessoal que se faz. (GESTOR DA COOPERATIVA C, 2013).

Mas isso é as pessoas novas. Quando tinha outras... Quando a gente fundou a cooperativa e as pessoas fundadoras e aí... Participaram e depois cada um acabava procurando emprego, né? Cada um vai vivendo o teu lado. E aí as pessoas novas que veio... Mas aí elas estão participando bastante. (GESTOR DA COOPERATIVA A, 2013). 
Há também a dicotomia entre empregado-empregador e cooperado cooperativa, em que os cooperados se sentem como "empregados" da cooperativa e não como sócios. Um dos gestores situa que "a gente bota que eles são sócios e não são empregados, então se a gente estiver bem, eles estão bem. Se a cooperativa cair, eles também caem" (GESTOR DA COOPERATIVA A, 2013:). Esta é a pior relação: quando há a configuração de relações empregatícias há o desapego pela responsabilidade de resultados. Quando há a cultura cooperativista, há a responsabilização pelos atos em relação à cooperativa: quando o negócio é "meu", eu me dedico mais; esforço-me mais; a responsabilidade é "minha".

Neste sentido, são desenvolvidas ações fortalecendo os laços com a cooperativa, a questão da cooperativa "ser sua" e você ser responsável direto pelo seu sucesso.

[...] a gente bota que eles são sócios. Eles têm que ajudar a cooperativa. A gente não bota a cooperativa como se fosse uma empresa. Que eu sou patroa, entendeu? Tem que ter alguém para administrar, sempre tem que ter alguém nesse lugar. Se tem lucro, tem lucro; se tiver prejuízo, tem prejuízo (GESTOR DA COOPERATIVA A, 2013).

Mas como esse processo de ampliação da cultura cooperativista ocorre? São desenvolvidas ações para as cooperativas se aproximarem das pessoas. Um dos gestores situa que a produção da cooperativa simplesmente "não decolava". Uma das ações desenvolvidas foi o de aproximação com pessoas da comunidade. O diálogo foi facilitado pelo fato de existir uma linguagem comum. Os universos foram aproximados.

[...] ficamos quase 1 ano patinando. Aí o quê que aconteceu... Alguém sugeriu que trouxéssemos alguém da comunidade, próxima aqui, [ENTREVISTADO CITA LOCALIDADES], um monte delas que tem aqui, pra trabalhar juntos. Foi, vamos dizer assim, o grande fator de motivação pra eles, porque a distância entre o nosso universo e o universo deles era tão grande que eles jamais gostariam de chagar no nosso universo. Mas do universo deles para aqueles que já moravam na comunidade e tinham um barraquinho, era muito grande, mas era muito próxima deles, então era motivação pra juntar alguma coisa pra poder comprar um barraquinho. Então aí o trabalho disparou (GESTOR DA COOPERATIVA C, 2013).

Houve, com esta aproximação, o reconhecimento e comunhão, pois existem pessoas que se veem como iguais, o que facilita a mutualidade das ações e fortalecimento das relações sociais, além de maior respeito e identificação e a solidariedade. Aqui, também apontamos, no questionário, o fato de existir projetos de alfabetização que vão além dos cooperados. E que quando há esses projetos (cursos, palestras etc.), a assiduidade é significativa. O Gestor B queria montar uma escola simples no galpão da cooperativa, mas não tem recursos para tal; o Gestor A já desenvolve essas ações e, agora, pensa em 
língua estrangeira e cursos profissionais. Ressaltamos que, segundo os gestores, uma minoria dos cooperados sabe ler e escrever.

Interessante destacar que as cooperativas surgem na comunidade local. 0 empreendimento visa mudar a realidade local. Quando perguntados sobre o início das cooperativas os gestores são taxativos ao informar a realidade local, um esforço de um grupo pequeno do local, com a finalidade de mudança, como motivadoras da criação do empreendimento. Também ressalta a necessidade socioeconômica como fator determinante ao trabalho com a coleta seletiva.

$\mathrm{Eu}$ fui trabalhar porque estava necessitada, desempregada. Quando eu comecei, eu comecei a trabalhar na Usina Verde como catadora na esteira mesmo (GESTOR DA COOPERATIVA A, 2013).

Eu formei com os amigos da comunidade. As pessoas da comunidade. Eu via aquelas pessoas desempregadas, sem ter uma ação, uma expectativa. Eu dizia 'gente é tão bom, vamos voltar pro nosso lixão, nós estamos deixando o lixo lá abandonado. Vamos voltar lá pra cima' (GESTOR DA COOPERATIVA B, 2013).

Bem, tudo começou há uns 25 anos atrás, 20 anos, 25 anos mais ou menos que nós dávamos comida na rua todas as noites. Nós saíamos com vários voluntários a noite pra distribuir quentinha. Chegamos a distribuir $130 \mathrm{mil}$ refeições por ano. Todas as noites saía um grupo. Depois quando eu me aposentei da Marinha, porque eu era Capelão da Marinha. Cheguei a Capelão-chefe, da Marinha. Nós pensamos naquela velha frase "o importante não é dar o pão e o peixe, mas uma vara pra pescar", começamos uma parceria com a Marinha porque esse galpão pertence à Marinha, com a Comlurb. E pegamos população de rua e separadores de papéis de rua, porque eles faziam aquela bagunça de rasgar o saco, tudo isso... Principalmente do centro da cidade e trouxemos pra cá. No intuito de darmos um local pra eles trabalharem, protegidos do sol, da chuva, tudo isso, com as refeições e também pra eles poderem dormir, aqui no outro galpão que é anexo a este. Então esse foi o início da coisa (GESTOR DA COOPERATIVA C, 2013)

Estes mesmos gestores dão muito valor ao lixo. Foi de onde tiveram oportunidade de conhecer pessoas que mudaram suas vidas, mas principalmente de onde tiraram o sustento das suas famílias.

Pra mim foi tudo né? Pra mim, pra minha família, porque aqui que é o ganha-pão da minha casa, como de todos que tem. E gerar emprego, né? Botando muitas pessoas aqui, muitas mesmo. Aqui a gente tem 63 pessoas trabalhando (GESTOR DA COOPERATIVA A, 2013).

Então eu criei meus filhos no lixo. Estou até hoje vivendo no lixo com meus filhos [...] E foi aonde eu criei meus filhos, foi através da reciclagem do lixo (GESTOR DA COOPERATIVA B, 2013). 
O trabalho nas cooperativas é penoso e insalubre - "você vê: já morreu muita gente. Porque isso aí traz muita contaminação... de tuberculose, e gente com sífilis... essas coisas que pega do lixo, entendeu?" (GESTOR DA COOPERATIVA B, 2013). Como situado no questionário, as cooperativas possuem equipamentos de proteção individual (EPIs), mas em quantidade insuficiente. Destaque para o fato de que quando se tem EPIs, alguns cooperados não utilizam os mesmos. Outro ponto a salientar é que na maioria das cooperativas existem pessoas responsáveis pela segurança do trabalho dos cooperados que não realizaram cursos específicos, mas que tem conhecimentos básicos.

Ainda que todo esse trabalho seja penoso e insalubre, o ambiente é caloroso e amigável. As cooperativas são empreendimentos solidários de fato. Mas a solidariedade aqui assume outro caráter, notadamente sobre as relações sociais. Como identificado pelos próprios gestores ao situarem a "amizade" (GESTOR DA COOPERATIVA A, 2013), como valores fundamentais do empreendimento. A amizade aqui, não se restringe somente às relações sociais, mas também nas relações de produção. Se um cooperado está impossibilitado de estar na cooperativa e, ainda assim quer contribuir, há a possibilidade de se criar mecanismos para que este cooperado contribua, como apontado na passagem abaixo:

Uma tem um menino doente, então ela cata em casa. E digo "não fulana, não precisa ir pra cooperativa não. Você tem que dar assistência ao teu filho". Porque até hoje ela correu atrás e não resolveu o problema do filho dela. Ele parece que já tá com 18 anos e tem problemas mentais. Então ela tem que focar tomando conta dele. Vai deixar um garoto doente em casa, sozinho? [...] E a outra também tá desempregada e então tá trabalhando na casa dela. E eu tenho outra... Aqui, a Fulana, catadora na casa dela. Então essas já catam na própria casa lá na comunidade. A gente vai só apanhar esse material delas. Porque é um meio de ajudar. A cooperativa tá aqui pra ajudar. (GESTOR DA COOPERATIVA B, 2013).

A situação de solidariedade e vontade de intervenção social é mais nítida nos casos em que envolvem os catadores de rua. Estes, ainda que não sejam cooperativados e, em uma determinada perspectiva, possam ser considerados como atravessadores no sistema de coleta seletiva, pelo fato de determinarem nos preços e na disponibilidade de material, não são discriminados pelas cooperativas, muito pelo contrário, são estimulados a se associarem e, se não se associam, costumam vender seus materiais às cooperativas.

E os catadores de rua. Aqui tem muito catador de rua; eles vêm e trazem o material a gente paga na hora o materialzinho deles, que é pra eles sobreviverem. Fulano, a gente fala 'vocês vêm pra cooperativa trabalhar que a cooperativa tem tudo de melhorar a vida de vocês' (GESTOR DA COOPERATIVA B, 2013). 
Mas a questão dos atravessadores é bem nítida e cruel. A princípio, o catador de rua é um "atravessador", mas um atravessador "inocente". Inocente em termos, pelo fato da necessidade que o mesmo tem de dispor de dinheiro ao fim do dia de trabalho.

A gente atende muito porque agora a coleta da prefeitura que tá trazendo. Laranjeiras, Ipanema, Tijuca. A gente pega esses bairros todos pra cá e nós aqui na comunidade aqui os catadores catam e nós vai com caminhão pegar nas casas deles. Alguns, porque tem alguns catadores que vende pro ferrovelho. E tem catador lá dentro que vende pro ferro-velho, mas alguns catam e nós vai buscar nas casas deles. [...] quando esse caminhão da Cumlurb da coleta passa, o catador já passou colhendo, já tirando o PET, já tirou o PP, já tirou o ferro, já tirou tudo. Quando chega aqui, chega o bagaço da laranja. (GESTOR DA COOPERATIVA B, 2013).

Mas há casos extremos. Outros atravessadores, além de atingirem a produção das cooperativas, atuam muitas vezes de forma ostensiva e violenta. Ou não é violência roubar os materiais de uma cooperativa?

[...] existe muito atravessador. O atravessador é o pior que tem. Ele chega aqui, quer botar o preço que ele quer [INAUDÍVEL], cada vez... Eles ficam até aborrecidos. Sabe? Tem uns que eles levam a carga dos outros e somem com a carga dos outros. Aí o pessoal fica doido querendo pagar os pessoal, porque eles somem. O padre tava reclamando numa reunião. Disse que teve um pessoal que foram lá comprar lá nele e levaram a carga dele. Não sei... Sumiu. Ele tava desesperado. Ele tava na reunião com a gente. Tava falando se a gente conhecia um cara que tava comprando. É tanto da gente sabe? (GESTOR DA COOPERATIVA B, 2013).

Vale um registro de suma importância aqui: antes de proferir e ao longo da fala acima citada, o gestor da cooperativa B diminuiu seu tom de voz, afirmando um posicionamento mais sério do que até então vinha ocorrendo durante a entrevista. O semblante do gestor mudou completamente: percebia-se desconforto e insegurança. Desconforto por aquela situação estar ocorrendo e insegurança não no sentido de formulação imprecisa de argumentos, mas de proteção.

Não obstante, há as dificuldades da operacionalização dentro da cooperativa. Nas visitas às cooperativas, é nítida falta de infraestrutura: a falta de banheiros adequados, galpões abertos, tetos esburacados (quando há teto!). Algo interessante a ser registrado é que quando entramos nas cooperativas visitadas, não foi percebido cheiro de lixo, o que é comum quando há lixo orgânico misturado ao reciclável. Todas as cooperativas, inclusive, possuem suas metodologias quanto ao asseio do local e à necessidade de se ter atenção com o lixo orgânico. 
de lixo aqui dentro da sua cooperativa, a gente chega por aí e tem lugar com cheiro de lixo". Eu digo "é que eu me preocupo... eu explico pra eles que não pode deixar o lixo ficar três dias". Quando... o caminhão chegou hoje, esse de hoje eles não vão limpar hoje, só vão limpar amanhã, vão terminar o anterior, depois que termina aquele anterior vão limpar aquele. E depois vai pra outro novo. Então é assim eu nunca deixo o material ficar velho. Porque o material pode ficar velho e mais tarde dar alguma... (GESTOR DA COOPERATIVA B, 2013).

Os gestores destacam que a iluminação e ventilação dos galpões não são adequadas à produção e segurança das pessoas. Os mesmos apontam que são necessárias melhorias urgentes a exemplo: escoamento pra chuva; pintura; conserto do teto esburacado; telhado; ampliação do espaço físico; banheiros; saneamento. Como trabalhar em um ambiente insalubre, sem as mínimas condições?

Mas há outros problemas. Estes são os que não faltam em uma cooperativa de catadores de materiais recicláveis. Os gestores divergiram quando aos problemas cruciais às cooperativas. Um deles destacou o baixo valor de venda dos materiais.

Porque a maior dificuldade hoje em dia é a venda dos materiais. Por quê? O país tá parado em termos de indústria, não tá consumindo tantos recicláveis, então o preço cai muito. O preço cai muito, e o quê mais? A China tá oferecendo matéria-prima pura, que tem um aproveitamento de $100 \%$. Essa matéria que é gerada aqui, as indústrias aproveitam de 80, 70 a $90 \%$ da matéria, mas tem gasto de energia, tem gasto de quebra de máquina, tudo isso. E a matéria-prima vinda da China pura é mais lucrativa. Então isso é uma das dificuldades que nós sentimos (GESTOR DA COOPERATIVA C, 2013).

Outro gestor destacou a falta de documentos como um entrave. Para este, as cooperativas não podem diversificar seu trabalho, nem atender novos clientes por esbarrarem na burocracia na obtenção de licenças, estatutos etc.

Como estava falando aqui. Cooperativa não pode também atender todo mundo. As cooperativas... a gente tá atendendo, até pela Licença Operacional. A gente conseguimos, mas fica difícil. Tinha que ver alguém pra tirar a documentação dessas cooperativas, pra gente poder estar dentro, porque em outro lugar não á aceito por causa do documento. Então como é que vou tirar um documento desse? A gente conseguimos. A gente temos a licença, temos Estatuto, temos Ata, temos tudo, mas a maioria das cooperativas não têm a licença, entendeu? E aí quando tem algum trabalho assim grande, a empresa pede e a ficar fora... Falta de documentos (GESTOR DA COOPERATIVA A, 2013).

Na questão burocrática, algumas cooperativas tiveram auxílio de pessoas de fora da cooperativa. Destaque para a Incubadora Tecnológica de 
Cooperativas Populares, da Universidade Federal do Rio de Janeiro (ITCP). A ITCP foi citada tanto pelo Gestor A, quanto pelo Gestor B. Só que no caso deste último, a ajuda foi de outra pessoa. A questão de documentação é essencial, podendo ser considerada um entrave à coleta seletiva. Para atuarem devidamente "na lei", as cooperativas necessitam estar registradas no Cadastro Nacional de Pessoas Jurídicas (CNPJ), possuírem Ata e Estatuto e, especificamente na coleta seletiva, possuírem licenças ambientais, além de cumprir em dia com o Manifesto de Resíduos.

Trazendo uma situação prática comentada e muito utilizada academicamente está a situação de determinado gerador de resíduo (que pode ser um condomínio, um hospital, uma empresa, um comércio etc.) que possui uma quantidade considerável de resíduos. Se ele quiser doar para uma cooperativa situada próxima, ele deve exigir o Manifesto de Resíduos. Este documento atesta a quantidade de material doada, registra quem recebeu a doação e atesta para onde este resíduo será disposto. Até o momento em que o resíduo é disposto, a responsabilidade é de quem doa; e não de quem recebeu, muito menos de quem depositou. Um outro exemplo prático está nos Editais públicos que exigem CNPJ, licenças e manifestos. Tais documentos são difíceis de serem obtidos se as cooperativas não são bem orientadas.

Tive de uma pessoa muito boa da Marinha. Ela agora está morando no Rio Grande do Norte. [ENTREVISTADA CITA NOME]. Ela que me ajudou a criar esse estatuto, a fundação da cooperativa. Quando ela chegou aqui, nós trabalhávamos e não tinha documento nenhum. Trabalhava aquele monte de mulher aqui dentro sem documento. Nós trabalhamos mais de dois anos aqui sem documento da cooperativa. Então ela veio aqui, era uma pessoa amiga minha, uma pessoa muito boa. Essa mulher, eu devo uma grande favor a ela. Ela chegou aqui e disse "mas fulana, você tem que procurar oficializar isso aqui, isso aqui é uma coisa muito bonita que vocês estão fazendo". [...] Ela foi uma pessoa que me deu um incentivo muito grande e hoje ela está no Rio Grande do Norte (GESTOR DA COOPERATIVA B, 2013).

Na ITCP [Incubadoras Tecnológicas e Cooperativas Populares, da Coppe/UFRJ], a documentação foi feita por lá, os cursos foram feitos por lá. [...] E eles [ITCP] ajudaram a gente muito em relação à documentação e tudo. Aí teve reuniões, teve pessoal também para poder trabalhar com o reciclável, todo o curso (GESTOR DA COOPERATIVA A, 2013).

Outro gestor destacou a falta de materiais básicos à própria produção na coleta seletiva, a exemplo de bags e lonas adequadas. Tais equipamentos facilitariam a locomoção e não exigiram grande esforço físico dos cooperados.

Eu queria tanto que eles mandassem uns sacos que tem na Comlurb, que as mulheres lá já tem esse saquinho porque é uma coisa melhor pra se trabalhar. Porque essas lonas são muito pesadas. Uma lona dessas pesa quase $120 \mathrm{~kg}$. A gente só falta morrer pra botar uma lona dessa no caminhão. E gente tá 
querendo que eles procurem melhorar a situação aqui da coleta sobre esse jeito que a gente tá trabalhando. Modificar né? Do bag pro saco, saco pequeno (GESTOR DA COOPERATIVA B, 2013).

No questionário, os gestores apontaram que há falta de máquinas e equipamentos básicos à produção, a exemplo de: esteira; prensa e empilhadeira. $E$, na possibilidade de investimento, as prioridades recairão sobre a aquisição de veículos, máquinas q equipamentos, treinamento e buscar por novos associados.

Todos os gestores foram unânimes em afirmar que o principal entrave nas cooperativas é a questão logística, notadamente, na falta de caminhão próprio. É basilar a qualquer cooperativa ter o seu caminhão. O sistema de coleta seletiva no município do Rio de Janeiro é coordenado pela Prefeitura, pelo Instituto Estadual do Ambiente (INEA) e tem o auxílio da FEBRACOM. Segundo os gestores, a FEBRACOM disponibiliza caminhões que atendem a todas as cooperativas cadastradas na entidade. São mais de vinte cooperativas para somente quatro caminhões. No questionário, os gestores situaram que a logística é feita por meio de parceiros; e que não realizaram empréstimos bancários para a aquisição de veículos. A aflição dos gestores pode ser percebida pelas passagens a seguir.

E os caminhões são bem pouco. O problema nosso é transporte. O que pega é que não dá pra gente atender tudo, porque fica muito transporte. [...]O caminhão aqui da rede da Febracom. A gente tem dois caminhões, mas é pra atender 20 cooperativas. Quando você vai agendar, você consegue de $15 \mathrm{em}$ 15 dias, duas vezes ao mês. Então fica difícil. [...] Primeiro, como te falei a cooperativa começando, ela atende, mas muitas não atendem por causado problema das cooperativas estarem tudo sem caminhão. (GESTOR DA COOPERATIVA A, 2013).

A gente aqui não ganhou o nosso caminhão. Nós vivemos [INAUDÍVEL]... a FEBRACOM manda o caminhão pra gente, a gente usa. E não temos caminhão, por que você vê uma cooperativa grande dessa daqui aonde poderia ter um caminhão pra cooperativa, não só a minha, que existe várias cooperativas que não têm seu caminho. O caminhão [da FEBRACOM] é pra servir não sei quantas cooperativas. Um dia eu tô com o material pra pegar no Banco Central do Rio de Janeiro e eu não tenho caminhão pra apanhar. Porque o caminhão já tava agendado e já tinha umas três pessoas na frente. Então quando o caminhão chegou, eu tive que mandar correndo pra atender as outras pessoas porque o lixo tava na porta na comunidade e eu atendi a comunidade primeiro, aqui que é a prioridade. Então eu tô no Banco Central com material lá preso lá porque eu não tenho caminhão. O caminhão hoje tá servindo a outras cooperativas, porque o caminhão não é só da cooperativa, é das cooperativas. Então quando ele vem aqui, vem um dia da semana, talvez vem dois, talvez vem mais. E vai atender outras cooperativas, porque são muitas cooperativas pra quatro caminhões. Não dá, não dá de jeito nenhum. A FEBRACOM, coitada, eles querem ajudar, eles querem fazer o que 
podem, mas não dá coitado, fazer o quê? (GESTOR DA COOPERATIVA B, 2013)

Olha, é um problema, não só a logística, porque, por exemplo, com essa conscientização toda, tem muitas empresas que dão muito material, mas esse material precisa ser retirado. Agora, é aquela coisa: nós fazemos essa parte, retirar. Infelizmente essa logística, ela sai cara. Nós aqui já chegamos a produzir ao mês 300 toneladas, 300toneladas/mês. Hoje estamos produzindo em torno de 70 toneladas. A luz que a gente gastava pra produzir 70 toneladas era, vamos dizer assim, a metade da metade da metade. Hoje produzimos menos e pagamos muito mais. Por quê? Porque o custo da energia subiu assustadoramente. O combustível a mesma coisa (GESTOR DA COOPERATIVA C, 2013).

A falta de veículos afeta diretamente as cooperativas. Sem capacidade de logística, elas têm de recusar o recebimento de materiais, pois não tem como atender a essa demanda.

O pessoal vinha trazer material aqui na porta pra gente. E a gente começou a falar que não queria mais material, porque não tinha condições, nós não tinha quem levasse, porque o rapaz disse lá que não podia mais apanhar. Eu até entendo a situação dele porque ele era o coordenador. Ele quer ver assim.... a cidade limpa também. Hoje eu entendo muito bem o que é que ele quis falar. Mas na época a gente com a situação de necessidade. A gente viu um caminhão de material e "não a gente não quer não", mandava embora porque a gente não podia pegar. Não tinha ninguém pra fazer a coleta (GESTOR DA COOPERATIVA B, 2013).

Apesar de todos estes problemas, os gestores comemoram o estágio atual da coleta seletiva. Houve mudanças nos últimos anos, principalmente com políticas públicas voltadas ao tema. Frente aos gestores das cooperativas, foi percebido que os gestores não conhecem o conteúdo na Política Nacional de Resíduos Sólidos. Ainda que, no questionário, todos responderam que conhecem a lei. Quando perguntados se conheciam a PNRS, eis as respostas.

Mais ou menos, porque não tenho tempo de ir pra esses lugares, eu vejo mais aqui (GESTOR DA COOPERATIVA B, 2013)

Sim, engavetada. Agora é isso aí (GESTOR DA COOPERATIVA A, 2013).

O gestor da cooperativa A pouco conhecia o conteúdo, mas sabia que ela é uma política que tinha ficado anos engavetada. O que demonstra que o conteúdo ainda não foi assimilado pelos gestores. Isto representa um perigo para a política e para a sua pactuação. Como pode um gestor desconhecer uma política que regula a sua atuação? Aqui se entende que os gestores possuem conhecimento técnico sobre a sua atuação e o setor, mas desconhecem a lei que regula todo o conjunto de suas atividades. 
Contudo, os mesmos indicam que a partir de 2010 houve mudança real na coleta seletiva. Pode-se afirmar, pelo cruzamento das informações obtidas que a Política Nacional de Resíduos Sólidos vem sendo efetiva sobre os policytakers, notadamente, as cooperativas de catadores de materiais recicláveis. Quando perguntados sobre a PNRS, se trouxe mudanças ou se o cenário da coleta seletiva mudou pós PNRS, os gestores dão afirmações contundentes de que houve mudança real após a sanção da Política Nacional de Resíduos Sólidos.

Trouxe, porque é obrigado a doar material pra gente. Mesmo assim está que $80 \%$, tá andando num ritmo direitinho, chamando a gente pra poder doar os materiais (GESTOR DA COOPERATIVA A, 2013).

[...] foi bom. Foi bom porque é onde as pessoas já estão conhecendo alguma coisa [...]. É por isso que eu digo, essas coisas veio mudar de 3 anos pra cá. De 3 anos pra cá que veio mudar isso aí (GESTOR DA COOPERATIVA B, 2013).

Ela vem fazendo a diferença porque há uma conscientização, uma preparação (GESTOR DA COOPERATIVA C, 2013).

Um dos gestores atribui a maior valorização da coleta seletiva ao governo Lula. Como expostos ao longo do trabalho, houve uma reorientação nas políticas sociais, com outros atores sendo "alvo" do novo governo

Mas graças a Deus, depois da gestão aí do nosso prefeito [Eduardo Paes], da nossa presidente [Dilma Rousseff], do nosso presidente [Lula], mudou muito essas coisas, porque eu já estive em Brasília, já fui pra São Paulo, já fui pra Minas Gerais, eu já fui em todos os lugares, há dez anos correndo atrás do que tá acontecendo hoje, que vem melhorar a coleta seletiva.[...] mas graças a Deus agora tá melhorando muito devido a esse conhecimento do nosso presidente, porque quem vem dar a honra pra coleta seletiva foi o presidente Lula. O Lula foi quem apoiou os catadores. É que falou em Brasília que o catador era uma pessoa trabalhadora igual a um funcionário do banco, igual a pessoas que fizessem qualquer serviço, entendeu? [...] Em Minas Gerais, quando o presidente [Lula] chegou lá, mas a presidente [Dilma], nós explicou toda a situação, que todos os lugares estavam sendo beneficiados, a Bahia, o Ceará... Vitória, vários lugares já estavam sendo ajudados. As cooperativas estavam sendo todo mundo ajudado. São Paulo, também. Minas Gerais, eu estou lembrando assim aos pouquinhos, porque tem muitas que estão sendo beneficiadas através do nosso presidente Lula. Então devido à nossa briga, eu ano retrasado eu levei a bandeira do Rio de Janeiro e falei pro povo "olha gente, o Rio de Janeiro tá precisando que alguém tome uma solução dos catadores, porque os catadores só tem trabalhado e trabalhado e ninguém vê nada, ninguém vê nada, ninguém vê nada" (GESTOR DA COOPERATIVA B, 2013).

Os gestores situam que há maior aproximação com o Estado, ressaltando a atuação do próprio movimento dos catadores como essencial a esse 
estreitamento das relações políticas e à própria reconfiguração das forças políticas. Mas este foi um processo lento. Um dos gestores, inclusive, destaca o papel de certos políticos na melhora do processo da coleta seletiva.

Tá bom porque a prefeitura tá aqui dentro. Tá ótimo. Já era pra isso estar há muito tempo. Há muito tempo que os catadores estão esperando isso. E agora nós estamos esperando que venha uma ajuda da própria prefeitura pra gente, ou do governo federal, quem se interessar de dar uma ajuda em cima da coleta seletiva pra gente. Porque... poxa, é muito trabalho que temos aqui. [...] O Estado pra mim... Eu não tenho o que falar do Estado porque esse trabalho que nós tínhamos da Serla, onde em 6 pessoas que trabalham lá, aqui da cooperativa foi eles que deram pra gente. O governo, o pessoal do INEA, a Marilene, o Minc, Carlos Minc que é uma pessoa muito... ele é muito influente no nosso trabalho, Carlos Minc é uma pessoa muito importante. Poxa, triste da gente se não fosse o Carlos Minc, ele tá sempre cobrando de um lado, tá sempre cobrando de outro pela reciclagem. Ele tá sempre apoiando a reciclagem, uma das poucas pessoas que brigam pela reciclagem e briga pelo catador. Que eu já cansei de ver, já tive em encontro com ele e eu só posso falar bem daquele homem (GESTOR DA COOPERATIVA B, 2013).

Vale situar que a principal mudança em relação às políticas públicas voltadas à coleta seletiva recai sobre a maior disponibilidade de material às cooperativas. Segundo os gestores, não era assim. Esse maior volume de doação de materiais veio a ocorrer de 2010 em diante. E, ainda segundo os gestores, a coleta seletiva operacionalizada por cooperativas tem tudo para aumentar ainda mais, justamente pelo aumento do volume de materiais doados.

Agora vai. Agora vai. Sabe o porquê? Aumentou muito assim o material, porque antigamente nós não tinha nada, nós comprava material. Vamos supor, comprava porque o catador vinha e botava ali e reciclava o material dele mesmo. Vinha, tava ali e a gente reciclava. Era muita pouca coisa. Era muito difícil (GESTOR DA COOPERATIVA B, 2013).

Dessa mesmo que falei pra você. As empresas não estavam doando assim. Doavam mais quando queriam. Ligavam e falavam: "você aceita material?". Agora não, elas são obrigadas. Tanto que elas têm o manifesto [de resíduos]. Elas procuram pra doar o material pra gente. Tá melhorando bastante (GESTOR DA COOPERATIVA A, 2013).

Um dos gestores alerta, contudo, que ainda com maior volume de materiais, o preço de venda dos mesmos é pouco valorizado. Há mais material para as cooperativas, só que o preço de venda ainda é baixo, ou seja, ainda que com mais material, o volume de recursos que entra na cooperativa ainda não é significativo o suficiente.

Olha, a Comlurb hoje tá com um projeto fantástico, bom... que seria o seguinte: hoje daria pra Comlurb coletar mais ou menos umas 30t de 
materiais recicláveis por dia, 30, 40t.... 30, 40 mil toneladas. Agora, o quê que acontece? Hoje, talvez, nós não reciclamos nem mil toneladas. Aqui, por exemplo, nós já, em épocas passadas, tivemos que a Comlurb despejava aqui 10 a 15 caminhões por dia. Nós tínhamos 120 pessoas separando. Hoje nós temos 40 pessoas separando e a Comlurb joga 3 caminhões. Diminuiu, mas por quê? Porque o preço tá muito ruim pra vender, então não adianta você ter aqui trocentas pessoas e você depois chega no fim do mês e não tem como remunerá-las. Então se ao despejar aqui fosse uma remuneração por parte da sociedade, tem imposto pra tudo, tem taxa pra tudo, então seria uma maneira de fortalecer, e de melhorar as condições de trabalho dessas pessoas (GESTOR DA COOPERATIVA C, 2013).

Tal posicionamento da falta de recursos para investimento dentro das cooperativas é corroborado por outro gestor. As cooperativas não têm condições de realizar investimentos internamente. Se não há condições para incrementar as condições de trabalho, como pode o trabalho destas cooperativas se desenvolver plenamente?

A única situação ruim que tá acontecendo é a situação que tá aquele buraco que tem lá que a gente não tem condição de consertar, que tudo é caro [A ENTREVISTADA SE REFERE AO BURACO NO TETO DO GALPÃO] ... Fechar as laterais desse galpão, nossos banheiros são muito ruins, nós não temos um saneamento básico aqui. Nós temos uma situação difícil por isso, então o que a gente ganha não dá pra gente empregar aqui. Porque a gente ganha muito pouco, nós tem que ter a ajuda de alguém pra fazer isso aqui. Porque já tiveram o pessoal da prefeitura, aqui falaram que ia até dar uma olhada nos banheiros, dar uma ajeitadinha aí... Então eu tô esperando até ver quando eles vão fazer já que eles falaram que vão fazer né? Vamos esperar né... (GESTOR DA COOPERATIVA B, 2013).

As cooperativas vivem de promessas. Diversos gestores públicos prometem mudanças estruturais nas cooperativas, apontando que irão solucionar problemas ou oferecer condições melhores às cooperativas. $\mathrm{E}$ isso enche as cooperativas de expectativas sobre o que podem ganhar.

Que é isso que todas as cooperativas estão correndo atrás, porque o ganho é muito pouco. Tudo bem, é bom o que a gente ganha, mas não pode ficar parado. Uma ajudazinha do governo é muito bom pra gente, que a gente é de dia-a-dia, que o dia-a-dia a gente aqui trabalhando. Trabalhamos dia-a-dia. Tem dia que a gente trabalha até no feriado, saber porque? Pra gente não perder, pra gente ter um dinheirinho a mais. E se o governo viesse a dar uma ajuda pra gente, seria muito bom. A gente já descansava mais [INAUDÍVEL], porque você vê: isso aí existe uma verba muito grande, do BNDES, existe uma verba muito grande pro meio ambiente e até agora não chegou nas cooperativas. Todo muito tá esperando, eu já fui em várias reuniões do BNDES. Várias reuniões, vários cantos e dizem que vão ajudar os catadores. E até agora não chegou nada. Até agora não chegou nada. Nós 
estamos esperando e eu acredito no meu presidente que vai chegar. Eu acredito no meu presidente que vai chegar alguma coisa para os catadores aqui do Rio de Janeiro. Eu não falo só do Rio não, eu falo do Brasil. eu falo é de Brasil, sabe por quê? Foi todo o Brasil que tava lá e todo o Brasil confia no nosso presidente (GESTOR DA COOPERATIVA B, 2013).

Uma das principais "promessas" da PNRS era a da facilitação do acesso ao crédito, principalmente via bancos públicos a exemplo da CEF e do BNDES. Foi percebido, por entre os gestores, que há uma imensa dificuldade de acesso aos recursos do BNDES. Segundo os gestores, o BNDES formula editais simplesmente impossíveis de serem atendidos pelas cooperativas. Os próprios gestores desconhecem os motivos pelos quais o BNDES formula editais "complicados" para assumir. Quando perguntados sobre a situação do crédito para as cooperativas, os gestores a veem da pior forma possível. E sem crédito, as cooperativas tentam se ajustar como podem para cobrir eventuais e recorrentes despesas que por ventura venham a surgir.

Você sabe que tem certo edital que não dá pra você nem ir apanhar. Sabe por quê? Você pega o caminhão e bota aqui. Você bota $R \$ 30,00$ de diesel, não dá. Pra ir lá pra Campo Grande, naquela de Campo Grande... Quartel de Marinha de Campo Grande, na fábrica de peça, onde faz esses canhões. Você sabe que a gente vai lá, traz o material que ninguém... não tem coisa pra cortar, é um papelão que vem com ferro. É um material plástico que ninguém tá querendo aquele material. Então quando chega aqui, olha, tô com o caminhão quebrado. Quase $\mathrm{R} \$ 5.000,00$ o caminhão das cooperativas, tá quebrado lá. Eu chamei todo mundo e ninguém quis. Tô devendo, eu tô devendo porque eu apanhei dinheiro emprestado pra consertar o motor que arrebentou. Então teve que fazer um motor novo pra poder botar de novo pra trabalhar eles me ressarcirem mais tarde, vou ver o que eles vão fazer por mim [...] Olha, pra mim conseguir o dinheiro eu tive que pedir emprestado ali. Vou ali "fulano, me empresta $\mathrm{R} \$ 2,00$, me empresta $\mathrm{R} \$ 1,00$ ". É assim, o banco não quer emprestar dinheiro pra cooperativa nenhuma. Eles não estão liberando nada. [...]Eu não sei quais são as dificuldades. Não sou eu. São todas as cooperativas com o mesmo problema. Não sei qual é o problema. Todas as cooperativas estão com o mesmo problema. Eu não sei, sabe? Só Deus. Eu tive que pedir dinheiro emprestado na FEBRACOM. Pra mim pagar... Sabe. Porque eles têm dinheiro lá em caixa e emprestou alguma coisinha (GESTOR DA COOPERATIVA B, 2013).

Aí eu vejo da forma pior possível, por quê? Porque o banco, o banco, ele quer lucro. Ele empresta o dinheiro, mas ele quer o retorno dele. Então você pega um negócio desses e não tem como pagar, porque vai custar muito mais. Agora, por exemplo, todos os cartões de créditos têm um monstro de dinheiro que eles têm que recolher para as obras sociais. Por que que eles não aplicam isso nas cooperativas, no lixo? Subsidiando, dando condições para que a gente possa ter? É muito difícil. Agora, se você chegar para um 
banco e provar que não precisa do dinheiro, ele vai te emprestar. Aí... (GESTOR DA COPERATIVA C, 2013).

São projetos que demoram muito. O projeto demora muito e também. Eles olham pra você e não tem nenhum acesso... Que eu conheça apenas três cooperativas no meio de não sei quantas que conseguiram, acho que 50 cooperativas. Porque eles pedem muita coisa. Muita coisa mesmo pra entrar. É muito difícil. E fora que pra liberar é mais ainda. Liberar dinheiro, entendeu? Então é muito difícil o crédito para as cooperativas [...] Eu já tô nessa - com o BNDES também, já tem uns 4 anos. E ainda não abriu os galpões. Um galpão que vai inaugurar agora é em Irajá. [O ENTREVISTADO se refere aos CTRs a serem abertos pela prefeitura do Rio] São seis galpões. Tem que lutar. Não pode desistir porque as coisas demoram, né? Cooperativa mesmo pra viver, como a gente vive, tem que ser com nossos pés. Entendeu? É assim: "vai dar ali", "vai dar aqui" (GESTOR DA COOPERATIVA A, 2013).

Neste cenário de adversidades, em que cooperativas se voltam a produzir como podem, a atender como podem, os gestores divergem quanto à existência de concorrência entre cooperativas. Alguns situam que há concorrência por materiais, editais e apoio público, enquanto outros entendem que não, que não há concorrência, pois o mercado é grande e o volume de recursos também. Os que veem a existência da concorrência a veem como negativa.

Porque até em buscar mesmo investimento público. Não tô defendendo a cooperativa, mas a cooperativa está sempre participando de tudo. E as pessoas, tem cooperativas que quer buscar onde tem as coisas boas, grandes. E quando tem chamamento público para coisas menores, eles não querem, né? Mas é nos menores que a gente cresce (GESTOR DA COOPERATIVA A, 2013).

Não, não. Em absoluto. Não existe essa concorrência. Tem pra todo mundo, dá pra todo mundo, e a gente pode fazer (GESTOR DA COOPERATIVA C, 2013).

Por outro lado, foi percebida uma intensa consciência política e a necessidade de fortalecimento dos laços entre cooperativas e cooperados e entre cooperativas entre si. A dificuldade de fortalecimento do movimento dos catadores e das cooperativas só pode acontecer com a convergência de interesses e a necessidade de engajamento político frente a outros atores da arena. O questionário indicou que mais de $65 \%$ dos cooperados vão às assembleias e participam e que mantém contato com outras instituições.

Há um, vamos dizer assim, um consenso e há uma visão comum sobre a dignidade desse trabalho que tá sendo realizado e a função que se desempenha. É a maior possível, é aquela coisa, está surgindo de baixo pra cima, um movimento, o movimento dos catadores, eles estão já se 
conscientizando do seu valor, do seu papel social, da sua função, tudo isso... isso é importante (GESTOR DA COOPERATIVA C, 2013).

[...] é como eu falei pra você. A nível nacional, nós somos. O movimento nacional, eu acho que nós somos o movimento nacional. Não pode ter divisão, entendeu? Não pode ter divisão porque nós somos catadores. Se tiver divisão começa a prejudicar a nossa classe. E a nossa classe não pode ser prejudicada por que a nossa classe já vem sendo prejudicada há mais de 50 anos. Então nós queremos ter evolução. Evoluir, as coisas que evoluam, que as coisas cresçam e não andar pra trás, que eu já tô cansada de andar pra trás. Quem anda pra trás é caranguejo (GESTOR DA COOPERATIVA B, 2013).

O fortalecimento dos catadores perpassa a relação da cooperativa com os mesmos. É um trabalho diário, de amizade, de participação, de solidariedade, de estar juntos, de mudança de mentalidade individual para a coletiva. De entender que o trabalho de um impacta na cooperativa como um todo.

A relação é uma relação de confiança mútua, e confiança não é uma coisa que você conquista da noite pro dia e de repente. Você tem que conquistar no dia-a-dia, estar juntos ali, brigar juntos, e dar passos. Respeitar o universo deles e também respeitar a caminhada, a mudança de mentalidade, tudo isso. Isso é importante. Nós gostamos sempre de querer mudar rapidinho todas as coisas e tudo. É um trabalho de começar todos os dias as mesmas coisas (GESTOR DA COOPERATIVA C, 2013).

As cooperativas estão fortalecendo e estreitando as relações entre si e com outros atores. A formação de redes solidárias e de participação é fundamental às cooperativas. O Movimento Nacional dos Catadores de Recicláveis (MNCR) e a FEBRACOM são atores muito citados pelos entrevistados, notadamente, este último, a FEBRACOM, que atua fortemente entre as cooperativas, facilitando materiais, equipamentos e é a base da logística das cooperativas.

Porque estão todos no mesmo ponto que estou. Estão sofrendo. Sei que ninguém tá bem. Alguns estão mais ou menos, que ganharam seu caminhão. A gente aqui não ganhou o nosso caminhão. Nós vivemos [INAUDÍVEL]... a FEBRACOM manda o caminhão pra gente, a gente usa. E não temos caminhão, por que você vê uma cooperativa grande dessa daqui aonde poderia ter um caminhão pra cooperativa, não só a minha, que existe várias cooperativas que não têm seu caminho. O caminhão [da FEBRACOM] é pra servir não sei quantas cooperativas (GESTOR DA COOPERATIVA B, 2013).

A gente tem uma rede na Febracom. [A entrevista cita o endereço da entidade]. Agora mesmo tá tendo uma reunião lá. $\mathrm{O}$ pessoal é associado à Febracom, às cooperativas. Acho que são umas 20 cooperativas já nessa rede, que tem a Eco Barreiras, o INEA, tem tudo direitinho para organizar a cooperativa (GESTOR DA COOPERATIVA A, 2013). 
A FEBRACOM acabou de me dar essa balança aqui, que a gente tem aqui. Nós vamos pesando os materiais, e tem todas essas reuniões para sincronizar esse trabalho (GESTOR DA COOPERATIVA C, 2013).

Por outro lado, ainda que a PNRS tenha surtindo efeito, as cooperativas se fortalecendo e o cenário da coleta seletiva começando a melhorar, os gestores situam que as leis são perfeitas, mas pecam na aplicabilidade e na falta consenso. As leis são perfeitas, segundo um dos gestores, mas não tem consenso, pelo fato de certos atores não terem sido chamados à mesa de negociações. Um dos gestores das cooperativas, talvez pelo fato de ter um grau de escolaridade maior que o dos outros gestores, faz uma análise mais profunda sobre as leis serem capazes de absorver aspectos fundamentais da resolução de um problema público. Em suas palavras:

[...] o nosso país é um país muito perfeito em leis, tão perfeito se cumprirmos todas as leis vai ser difícil a gente conseguir trabalhar porque, porque vai engessar de todos os lados (GESTOR DA COOPERATIVA C, 2013).

Esse gestor dá o seu relato sobre como as leis são conflitantes muitas das vezes. Se, por um lado, existem leis que permitem o trabalho das cooperativas, por outro lado, existem leis que impedem este trabalho.

Eles proibiram que nós tivéssemos um hotel de trânsito aqui. Nós montamos uma estrutura para que eles dormissem em redes, que era o mais simples, o mais barato, cada rede custava $\mathrm{R} \$ 5,00$, não precisava lavar, não tinha contaminação, não tinha nada e cada rede era deles. Era sua rede. Quando ele quisesse ir embora, levava a rede dele e acabou. Mas as autoridades sanitárias, preferem que eles durmam na rua do que dormir ali, porque, por causa disso e daquilo, não tem ar-condicionado, ventilação... Proximidade do galpão da reciclagem, então... Condenou. Então tivemos que desistir desse projeto (GESTOR DA COOPERATIVA C, 2013).

Importante destacar que o gestor da cooperativa C apresenta um posicionamento em que, de um lado apoia as leis, mas pondera que muitas delas prejudicam o trabalho desenvolvido. Desta forma necessita fazer ajustes no próprio trabalho desenvolvido. Este mesmo gestor tem um profundo conhecimento das leis e da necessidade de maturação das mesmas. Este gestor tem noção de que as leis que reestruturam processos e forças políticas são projetos de longo prazo. Neste contexto se enquadra a própria Política Nacional de Resíduos Sólidos.

Agora, graças a Deus, que estas políticas todas estão sendo implantadas, muito bem implantadas e ela vai ter um tempo de maturação, de assimilar, tudo, pra começar a produzir frutos. Só que nós brasileiros somos imediatistas e queremos o fruto pra ontem. Não é bem assim que funciona a coisa... [...] Olha, os passos a serem dados, de todas as cooperativas, se você correr as cooperativas, quase todas elas, elas estão, vamos dizer assim.... no 
processo de legalizar a situação deles. Porquê? Porque como eu disse anteriormente, são muitas leis, que te cobram de todos os lados, e pra você regularizá-las, você tem todo um processo que você precisa aos poucos... então você trabalha, ou então você corre atrás das leis. Mas a lei vai te dar algum benefício imediato? Não, então você tem que deixar um pouquinho, daqui a pouco eu faço, depois eu faço, e vai indo assim. É todo um processo, é uma engrenagem que caminha muito devagar. Então a gente não tem como mudança mudanças radicais da noite pro dia, como a maioria das pessoas pensam que pode ser feita. Não é fazendo uma lei que no outro dia essa lei tá na prática (GESTOR DA COOPERATIVA C, 2013).

No caso da Política Nacional de Resíduos Sólidos, a figura mais fraca da correlação de forças é a cooperativa de catadores de materiais recicláveis. Por conta disso, foi editada a Lei no. 12.690, de 19 de julho de 2012 que dispõe sobre a organização e o funcionamento das Cooperativas de Trabalho. Esta lei procura dar mais segurança aos cooperados. No entanto, segundo os gestores, pelo momento atual das cooperativas, a Lei no. 12.690/2012 é um retrocesso e prejudicará o funcionamento das cooperativas, por exigir das mesmas, o cumprimento de itens que não são capazes de atender.

O Brasil tá despertando para o cooperativismo, principalmente para a reciclagem de material, os estatutos dizem que ninguém pode ganhar menos que 1 salário mínimo. Tudo bem, isso aí é um princípio e a filosofia fantástica, só que com os preços que os materiais são vendidos, a gente não consegue atingir esse salário mínimo. Então isso aí se torna um mito, uma maneira de sufocar e muitas delas não conseguem sobreviver em cima disso (GESTOR DA COOPERATIVA C, 2013).

Não tenho condições. Como é nós vamos pagar se nós não temos condições? Agora se o governo federal der um reajuste pra gente, pra gente poder pagar pelo menos. Eu pago o meu INSS, eu pago, mas tem muita gente aqui que não pode, mas eu pago, sabe o porquê? Eu faço biscate na minha casa, eu sento lá na máquina, eu costuro. Faço uns remendinhos pra mim vender, pra mim pagar meu INSS. Tô com as minas pernas doente, eu não posso nem ficar... de noite eu grito com essas pernas de dor no joelho. Por causa de ficar costurando, pra ter mais uma coisinha, pra aumentar o meu sustento. Chega lá, quando eu já chego cansada com as pernas doendo pra trabalhar e puxar esses fardos grandes. Como é que esses pessoal... como é que a gente, o pessoal vai pagar INSS? Se as condições não dá [INAUDÍVEL], se a gente for tirar pra pagar INSS, essas coisas ficam difícil. A gente tem que ter ajuda do governo. Esse cheque verde vindo vai ser muito favorável pra eles. Aí a gente já vai ter condições de chamar todo mundo. Quando eu chamo todo mundo "oi gente, vamos pagar INSS", "ai dona fulana, vai tirar INSS da gente, e a gente vai comer o quê? a gente já ganha pouco, vai pagar INSS, vamos esperar melhorar". Eu digo "vamos esperar melhorar, que nosso presidente... já tá quase chegando lá, a coleta seletiva tá chegando aqui dentro, vai melhorar" (GESTOR DA COOPERATIVA B, 2013). 
Quando virar empresa a pessoa [o cooperado] não vai retornar mais. Não sei nem te responder isso aí... [...] Gerar renda a gente já gera, né? Mesmo sendo autônomo. Só que aí você tá botando a empresa e as pessoas vão ser pra trabalhar pra empresa. Não vão ser mais sócio. Aí vira uma empresa. Empresa... é uma grande coisa né? (GESTOR DA COOPERATIVA A, 2013).

As leis criadas visando a coleta seletiva têm como objetivo não só incentivar a coleta seletiva, sua expansão e adoção pelas prefeituras e administrações locais, mas sobretudo, atuar sobre os empreendimentos solidários, em relação as oportunidades de crescimento, do aumento de volume de materiais e especificamente sobre a melhoria da renda das cooperativas de catadores. Quando perguntados, os gestores indicaram que após a Política Nacional de Resíduos Sólidos e durante o governo Lula, houve melhora substancial na renda das cooperativas. Notadamente, esta melhora se deu ao aumento do volume de materiais recebidos. Alguns gestores procuram, com esta melhora percebida, dar maior conforto aos cooperados, oferecendo coisas que antes não existiam. A renda nas cooperativas se situa entre menos de 1 salário mínimo e 1 salário mínimo e meio. A maioria dos gestores vem atendendo a editais públicos de órgãos da administração do estado e do município do Rio de Janeiro.

As empresas não estavam doando assim. Doavam mais quando queriam. Ligavam e falavam: "você aceita material?". Agora não, elas são obrigadas. Tanto que elas têm o manifesto [de resíduos]. Elas procuram pra doar o material pra gente. Tá melhorando bastante. [...] Melhorou a renda. E mais emprego também. Começamos com 15 [pessoas]. E agora já deve estar com 70, 80 [pessoas] já (GESTOR DA COOPERATIVA A, 2013).

Poxa, é muito trabalho que temos aqui. Eu chego aqui é 6:40, eu boto o café no fogo e fico esperando as mulheres chegarem. Quando dá 7 horas, já tô com o portão arreganhado e elas entrando pra tomar café. Porque eu acho que a primeira coisa é o pão abençoado de cada dia que Deus deu pra gente. E aí depois da hora do almoço elas vão pra casa almoçar mas pelo menos elas tomaram o café da manhã e não estão em jejum. [...] Melhorou mais. Sabe quanto nós saía daqui, dia de semana? Eu saía com $\mathrm{R} \$ 20,00$, todo mundo aqui. Uma mixaria de dinheiro. Você vê o PET, o preço era lá embaixo, hoje em dia graças a Deus as coisas melhoraram mais. Já tendo mais... um precinho melhor pras coisas. [...] Melhorou a renda. Melhorou porque antes a gente tinha $\mathrm{R} \$ 420,00, \mathrm{R} \$ 500,00$. Nós não tirava isso, nós tirava nem $\mathrm{R} \$ 200,00$. Nem $\mathrm{R} \$ 100,00$ vem dizer por semana. Eu saía daqui arrasada, arrasada. Não tinha nada. A dificuldade nossa aqui foi muito grande. Muito grande. Muito grande. Muito grande. E espero em Deus, 
vamos esperar em Deus, que ele é santo vivo e poderoso (GESTOR DA COOPERATIVA B, 2013).

Como aqui é um trabalho social, e eu também tenho as minhas amizades eu peço muito, ou então alguém me dá material, tudo isso, então a gente compensa um pouquinho mais, porque aqui hoje nós estamos pagando, pra cada um que produz $\mathrm{R} \$ 0,10$ o quilo. Você poderia dizer "é pouco". É.... relativamente pouco, mas às vezes nós vendemos o material a doze, a quinze, às vezes baixa a oito, mas eu continuo pagando os 10 centavos, mas tem materiais como o PET, tudo isso, que estão muito acima disso, $\mathrm{R} \$ 1,00$. Mas aí também você tem café da manhã, almoço, lanche, jantar e cesta básica. Então tudo isso é custo. E precisa ser tirado daqui, e precisa ser feita essa química toda. Estamos estudando pra gente remunerar por preço diferenciado por cada material (GESTOR DA COOPERATIVA C, 2013).

Ao passo em que vão melhorando as condições mínimas de trabalho e de produção dentro das cooperativas, as mesmas já sabem onde investir, caso tenham possibilidades. Os gestores foram enfáticos ao apontar que a questão logística é o gargalo fundamental das cooperativas e que será a prioridade de intervenção, assim que puder ser atendida. A questão logística é um gargalo pelo fato de as cooperativas estarem recusando o recebimento de material, pois não tem como ir até o local e retirar, ou quando após a segregação não ter como escoar a carga.

Olha, essas empresas grande podiam entregar o material pra gente, entendeu? E os caminhões são bem pouco. O problema nosso é transporte [grifo nosso]. O que pega é que não dá pra gente atender tudo, porque fica muito transporte. Quando então gente paga a diária por fora. Ajudante não vale a pena, por que pelos materiais que tem vindo, sem valor (GESTOR DA COOPERATIVA A, 2013).

Nós estamos sendo muito é humilhados, humilhados, porque poxa, tinha pessoas da prefeitura que chegam aqui diziam "olha [ENTREVISTADA CITA O PRÓPRIO NOME], qualquer hora a gente vai vir aqui vai fechar o galpão, olha fulana esse material aqui fora", aí eu digo "meu filho, é o pessoal que vem e joga pra gente", pois a gente não tem ninguém pra dar pra gente. Então a gente ia lá fora e tirava o material e levava pra dentro, reciclava e o restante manda botar fora porque nós não tinha onde botar [grifo nosso]. Um caminhão pra levar o rejeito era $\mathrm{R} \$ 800,00$ que o cara cobrava ou a gente ganhava ou a gente largava por aí, ele dizia que ia dar multa e a gente ia levar multa, porque a gente não tinha condições de pagar um caminhão, os R $\$ 800,00$ (GESTOR DA COOPERATIVA B, 2013).

Por exemplo, esse caminhão aí, se ele foi pra Itaguaí, tá custando pra ele $\mathrm{R} \$ 150,00$ a tonelada. Ele leva em média 3 toneladas, $\mathrm{R} \$ 450,00$ custo de... aí tem o óleo, tem o motorista, tem o desgaste... Então você vê: é um trabalho que a sociedade tem que arcar com isso que é o que a gente produz. Então esse custo operacional é que dificulta o nosso trabalho. Agora, como poderia 
ser resolvido isso? Quando joga aqui esse material ou os outros materiais, a gente deveria ser remunerado pra poder compensar. Porque, por exemplo, se eu pegar um caminhãozinho nosso, pra ir até o centro da cidade, pegar, vamos dizer assim, no máximo, no máximo, $100 \mathrm{~kg}, 200 \mathrm{~kg}, 300 \mathrm{~kg}$, nós estamos pagando pra trabalhar. Porque o custo do combustível, a diária do motorista, o desgaste do caminhão, quase que não compensa [grifo nosso]. Então ele roda o dia inteiro, pra chegar no final do dia, aquilo o que é arrecadado não dá nem pra cobrir as despesas (GESTOR DA COOPERATIVA C, 2013).

O gestor da cooperativa B é o que melhor pondera essa questão logística como gargalo fundamental da coleta seletiva. Seu relato consegue sintetizar como a logística interfere no trabalho desenvolvido pela cooperativa: custos, tempo, perda de material, conflitos etc. quando perguntado, o gestor afirmou que a prioridade fundamental da cooperativa é a compra de um caminhão. Parece que ter um caminhão é o objeto de desejo de todas as cooperativas. A falta de um caminhão próprio configura as algemas da cooperativa dentro do sistema de coleta seletiva.

O caminhão. 0 primeiro seria o caminhão [grifo nosso]. Porque esse caminhão das cooperativas, graças a Deus que esse caminhão que recebeu agora, que a FEBRACOM recebeu até que tá dando certo, mas eu não posso dizer que eu tenho caminhão. O caminhão não é meu, é das cooperativas. Ele sai daqui vai pra [ENTREVISTADA CITA GESTORES DE COOPERATIVAS]. Vai pra tanta gente esse caminhão, que tem dia que eu fico aborrecida [grifo nosso], eu passo até mal de tanto o pessoal ficar ligando "fulana, como esse pessoal lá do Banco Central, tá cheia a sala, não posso ficar com essa sala cheia aqui não". Eu digo "ó meu filho, eu não tenho condições". Ele diz "então eu vou passar pra outra cooperativa". "tá meu filho pode passar". Eu vou deixar o homem ficar lá precisando e eu precisando muito mais do que ele. Ele tá jogando fora e eu preciso. Aí vai dar pra outra cooperativa que tem caminhão, que tem tudo, que tá correndo atrás, que tá agindo. Eu não, eu fico sempre atrás, sempre atrás. Eu tô vivendo hoje em dia com essa coleta seletiva. Não tem decreto nenhum. O único decreto que eu tenho é esse lá do Banco Central, que eu não tô conseguindo atender ele (GESTOR DA COOPERATIVA B, 2013).

Os gestores apresentam um alto grau de conscientização ambiental. Os gestores, inclusive, questionam o consumo excessivo; o que se está jogando fora; o desperdício de materiais, a educação ambiental etc. Um ponto fundamental levantada é a Educação. Destacaram que o material orgânico prejudica a própria coleta seletiva. O gestor da cooperativa $\mathrm{B}$ é o mais enfático 
desta questão; situa que a separação deve começar dentro de casa e não deve ser relegada aos catadores de materiais recicláveis.

[...] começar a falar com os moradores, que nós tínhamos que procurar separar o material, sabe? Procurar tirar mais o lixo orgânico [grifo nosso], porque o lixo orgânico é que prejudica todo o material de uma reciclagem. Tirou o lixo orgânico, pronto. Porque o lixo orgânico já vai servir pra plantação; as pessoas não sabem o que estão jogando fora. As pessoas estão alimentando pessoas que estão necessitando; está alimentando a terra, né? Porque se nós não dermos a matéria orgânica pra terra mais tarde a nossa terra tá fraca com tanta poluição que nós já conviveu com ela e estamos convivendo [...] Eu falo com eles e tô sempre falando. $\mathrm{O}$ pessoal que trabalha aqui dentro, mora dentro da comunidade e eles sempre fala que não pode, entendeu... o lixo ficar à vontade; as pessoas têm que começar a reciclar dentro de casa [grifo nosso], porque se nós não começar a reciclar dentro de casa, aí como é que vai ficar? Então a gente tá pedindo pra que as pessoas comecem a fazer esse trabalho e tá até passando pra... eu até escutei... parece que foi ontem que escutei que de Brasília, no horário de Brasília [A ENTREVISTADA SE REFERE AO PROGRAMA DE RÁDIO "VOZ DO BRASIL"] falando que as pessoas tem que começar a reciclar, começar a melhorar por causa do nosso planeta, porque o nosso planeta tá muito fraquinho [grifo nosso]. Se nós não cuidar dele, quem vai ficar doente somos nós (GESTOR DA COOPERATIVA B, 2013).

O gestor da cooperativa A aponta que a Educação é a base de mudança. Destaca que a coleta seletiva tem na separação um de seus principais problemas. Segundo ele, as pessoas (leia-se, consumidores e empresas) não estão separando corretamente os resíduos dos rejeitos e, desta forma, "tudo vai para a Comlurb". Por este motivo, a coleta seletiva ainda não está estruturada $100 \%$. Faltam educação e cultura em relação ao consumo, ao desperdício, mas principalmente quanto à disposição adequada dos resíduos, da reciclagem e recuperação dos mesmos.

Ela não tá $100 \%$ não. Acho que as pessoas podiam separar mais, porque ainda mandam muita coisa pra Comlurb. Mandam material misturado ou até quando mandam pra gente mandam com [INAUDÍVEL]... A gente perde. Acho que na separação (GESTOR DA COOPERATIVA A, 2013).

Todos os gestores situam que a partir da criação das políticas públicas voltadas à coleta seletiva, esta tem tudo para crescer e se estabilizar na gestão pública. Os gestores também destacam que com maior apoio do Poder Público, este setor tende a trazer mais frutos, não só à cooperativa, aos catadores, às empresas, mas à sociedade em geral. Para os gestores as cooperativas têm papel fundamental na coleta seletiva, pois sem aquelas, esta não existiria.

A cooperativa é muito importante porque se não fosse a cooperativa como é que ela existia? Então eu acho... A cooperativa tá em primeiro lugar, que é 
onde tá tocando as coisas pra frente. A cooperativa foi uma coisa assim, vamos dizer, uma coisa criada, uma coisa que... Triste da gente se não fossem as cooperativas. Que é onde as cooperativas, que é onde recebemos todos os trabalhos (GESTOR DA COOPERATIVA B, 2013).

Sucesso. Aumentar mais o trabalho. [INAUDÍVEL] Tá sendo uma correria. A gente tá ficando louco, mas tá bom. Quero que cada vez sobe mais né? Quero crescer. [...] E ainda por cima, vem muita luta ainda, muita luta ainda. [...] Em que sentido... Até de material mesmo que a gente busca, por que hoje em dia é doações né? Tem pessoas que ligam até pra vender ainda. E a gente não é ferro-velho, a gente é cooperativa. E como a gente... Como essa empresa é obrigada a doar esse material pra gente e eles ficam com o material fino e dá muito pouco pra gente, dá as coisas mais sem valor que é o papel, papelão. Pra gente tem valor, mas as coisas finas eles ficam (GESTOR DA COOPERATIVA A, 2013).

É tudo um conjunto de coisas que precisam ter uma política que não é só sentar e bolar o negócio, é ter todo o entorno: a operacionalidade, ver tudo, a sincronia, chamar as pessoas, sentarem e tudo isso. Mas tá faltando. Quem sabe, talvez, com o tempo, a gente consiga chegar lá. Eu espero que sim. E nós temos tudo pra isso. Se os outros países fazem, por que a gente não pode fazer? (GESTOR DA COOPERATIVA C, 2013).

Aqui está registrado nas falas dos gestores o processo de pactuação das políticas públicas. São políticas que necessitam da participação dos atores que serão afetados por elas. Paralelamente não basta a participação, mas o diálogo em canais abertos, com Instituições que assegurem a plena mobilização destes atores no processo de construção da política. Do contrário, acontece o cenário descrito pelo Gestor da Cooperativa C: uma plenitude de leis perfeitas que não conseguem ser seguidas e que acabam por engessar toda uma engrenagem que deveria fluir automaticamente conforme idealizado pelas leis.

Vale o registro de que um dos gestores se preocupa que com maior visibilidade da coleta seletiva, a necessidade de mais máquinas e equipamentos, há a possibilidade da tecnologia ser uma ameaça à figura do catador. Este gestor situa que máquinas e equipamentos são bons, mas são ameaça no momento em que a figura do catador que faz a segregação não for mais necessária. Este é o medo desse gestor: a figura do catador não mais ser essencial à coleta seletiva.

Com certeza, até porque quando começar a separar sozinho não vai ter mais catador. Não vai ter mais ninguém pra trabalhar. Agora esteira não, esteira é ótimo, porque a esteira tem que ter o catador. Agora daqui a pouco se botar quem faça sozinho não tem mais trabalho... As máquinas de trabalho pra cooperativa são legais: a prensa, a balança, esteira... Agora quando começar a separar sozinho e aí? (GESTOR DA COOPERATIVA A, 2013). 
A tecnologia de ponta não foi bem vista por esse gestor. Ele situa que não há possibilidade de agregar tecnologia de ponta com os catadores, pelo fato de que a máquina irá "engolir" o catador. A tecnologia é uma ameaça e está sendo muito bem observada pelos gestores.

Não há. Também não. Fora os outros... Porque tem que ter a esteira. Igual tem um braço, na Usina Verde, tem um braço que puxa dentro do container... Puxa lá, ajuda até porque ninguém vai aguentar. Mas ali fora tem um rapaz pra manusear aquilo e ajudar a puxar também. Mas aquele braço tá bom. Agora montar pra separação... Acabou o trabalho. Só se eu abrir uma empresa pra mim e eu trabalhar sozinha, tudo pra mim, né? Por que aí não tem catadores (GESTOR DA COOPERATIVA A, 2013).

A coleta seletiva necessita de aporte do Poder Público. As cooperativas de catadores estão vivendo uma situação de Desamparo Estrutural, ainda que estejam se estruturando e se organizando paulatinamente. Elas necessitam de tudo: auxílio jurídico no que toca um ambiente próprio, para que não sejam ameaçadas de despejo; auxílio financeiro, para que possam fazer reformas estruturais nos galpões e que possam obter maquinas e equipamentos; auxílio cultural e educacional, para que possam difundir a cultura do cooperativismo e melhorar suas técnicas de segregação; auxílio social, para que sejam capazes de estruturar ações voltadas aos cooperados e que possam estender para as suas famílias; auxílio logístico, com o objetivo de combater o gargalo fundamental que é a falta de transporte; e auxílio político, para que possam reequilibrar as forças políticas e sejam capazes de se fazerem ouvidas pelos agentes públicos.

É tudo. Infraestrutura também. As pessoas pra ver a cooperativa tem que ter o espaço, ter o lugar. E não é fácil não. Tem muitos lugares por aí que não é igual aqui. Hoje o sol tá lindo, mas quando chove... Alguma coisa eles tinham mais é que procurar a gente pra poder ajudar nisso (GESTOR DA COOPERATIVA A, 2013).

Tá sendo muito reaproveitado o material do Rio de Janeiro. E há três anos atrás não tinha essa opção. Eu sofri muito aqui nessa cooperativa, eu fui muito pisada, sabe o que é pisada? Por algumas pessoas da Prefeitura, eu não estou falando do nosso Prefeito [Eduardo Paes], porque ele não sabia de nada [...]Então eu confio no meu presidente e na minha presidente, porque eu tive direto, eu falei diretamente olhando pra ele "presidente o senhor tem que ver a situação que nós estamos passando, presidente, nós não tá aguentando mais". Eu senti o que o povo sente na pele aqui no Rio de Janeiro, o sofrimento que a gente tava sentindo, porque até disseram que iam mandar online pro Inea a situação que a gente tava passando. E que iam mandar não sei pra onde, pra prefeitura, a situação que a gente tava convivendo aqui, ele disse que ia mandar online, que ia me prejudicar, então, tá bom, vai me prejudicar e ia pedir pra ele, poxa meu amigo quebra essa 
daí, humildemente "não eu já mandei, já tô mandando", eu digo "tá bom". Sempre naquela humilhação, pisada, morta. Hoje em dia eu tô uma mulher doente. Doente de ter passado o que eu já passei. Tô com problema de colesterol, problemas de nervos muito grande, acho que estou até com aquele problema de pânico, com medo, entendeu? Tanta coisa que eu já passei, de eu querer ajudar essa comunidade minha, essa comunidade Marcílio Dias que vem sofrendo há muitos anos (GESTOR DA COOPERATIVA B, 2013).

Agora, o governo, as políticas sociais, de resíduos e tudo isso, tá fantástica, tá no caminho certo. Precisa ser ajustado ao longo da caminhada, não são críticas, são pequenos ajustes como tudo precisa ser feito. Ajustes pra poder funcionar e azeitar todas as engrenagens [...]Eu espero o seguinte: que esse processo de maturação e com o perfil deles assumirem as responsabilidades como a cooperativa, e assim conseguirem sobreviver nessa caminhada toda, aí eu posso ir embora, morrer, mudar, buscar outro setor pra trabalhar, alguma coisa assim. Então, meu trabalho vai ser esse: trabalhar com eles, ajudá-los, para que eles assumam esse papel (GESTOR DA COOPERATIVA C, 2013).

Mas este auxílio não é esmola social. As cooperativas não querem ser amparadas pelo assistencialismo; elas querem ser amparadas, observadas pelas políticas públicas, com o claro intuito de mudança transformadora positiva, em que há mudança no status quo, de forma permanente e que seja positiva. As cooperativas querem ser consideradas pelos policymakers em todo o processo de formulação de políticas públicas voltadas à coleta seletiva, pois são agentes e atores fundamentais no processo de gestão dos resíduos sólidos urbanos. Como criar um plano de gestão de resíduos observando a reciclagem e a recuperação de materiais se não se leva $m$ consideração agentes que são especialistas no assunto e que trabalham diretamente com o objeto da política?

Por último, este processo, é um processo lento, que envolve a coordenação de atores, a convergência de interesses e a necessidade de se atuar em conjunto. Um dos gestores situa a questão de prestadores de limpeza de dentro de órgãos que são obrigados a doarem seus resíduos, estarem atuando como atravessadores. Como pode um órgão público, que deveria doar todos os resíduos gerados, permitir que prestadores de limpeza retirem determinados materiais (os mais caros), e deixem para as cooperativas somente os materiais menos valiosos? As cooperativas de catadores já têm dificuldades de atender a um Edital público e, quando vão buscar os materiais prometidos, somente são retirados os materiais que possuem pouco valor de venda.

Porque dali mesmo tem prestador de limpeza. Isso é coisa de lá de dentro. Eles guardam pra festa de final de ano. E a gente tá sempre brigando por causa disso. Aí quando tem madeira eles querem dar. Eles querem dar só assim: papelão, papel. A única coisa que dão mesmo é até papelão, o resto de material não querem (GESTOR DA COOPERATIVA A, 2013). 
Neste ponto recorre-se à fala do gestor da cooperativa C. Este gestor é categórico ao apontar a discrepância entre aquilo o que é planejado e aquilo o que é realmente feito. Aponta também que os políticos que fazem suas políticas dentro de seus gabinetes sem ao menos chamarem aqueles futuramente afetados por ela, criam políticas frágeis, que não surtem efeito e que precisarão de ajustes.

A pior coisa que tem, é você ter os técnicos que sentam nos gabinetes e produzem as ideias, coisas que são boas, fantásticas, são necessárias, mas entre aquilo o que é produzido num gabinete àquilo que é a realidade tem um distanciamento muito grande. Então talvez se houvesse esse casamento de pegar algumas coisas da base pra poder levar e aperfeiçoar, então isso aí seria fantástico. Porque é um trabalho comum de todos. Agora, o governo, as políticas sociais, de resíduos e tudo isso, tá fantástica, tá no caminho certo. Precisa ser ajustado ao longo da caminhada, não são críticas, são pequenos ajustes como tudo precisa ser feito. Ajustes pra poder funcionar e azeitar todas as engrenagens (GESTOR DA COOPERATIVA C, 2013).

Esse gestor cita um caso prático, o da criação do Centro de Tratamento de Resíduos (CTR) de Irajá, na zona norte da cidade do Rio, uma das seis que serão implantadas e que servirão como molar propulsor da logística de resíduos sólidos no município do Rio de Janeiro.

Eles estão em fase de implantação. São 6 grandes galpões em que as cooperativas poderão levar o seu pessoal lá pra fazer a separação, e tudo isso. Isso é fantástico, é uma maneira de colocar e centralizar esse trabalho, unificar esse trabalho. É bom? - fantástico. Fantástico. Porém, fica a mesma questão sempre: na hora de vender, se o mercado estiver em baixa, e nós não conseguirmos um preço bom, como é que a gente vai fazer? Esses galpões... eles foram bolados, planejados, tudo isso... em escritório. Aí construíram, não perguntaram para aqueles que trabalham, resultado: eles tiveram que adiar a sua inauguração porque tiveram que refazer tudo de novo. Porque a funcionalidade do negócio não deu pra operar. Não tem esteira, não tem nada, fizeram... Então fizeram os centros, mas tinham alguns erros básicos e esses erros básicos atropelaram e muito, retardaram e tal... Então, muitas vezes precisa haver essa sincronia com aqueles que pensam bolam o negócio e com aqueles que trabalham, perguntando as informações, por exemplo, aqui já sonhei muito (GESTOR DA COOPERATIVA C, 2013).

Por outro lado, há a confiança de que este é um processo de maturação que vem ocorrendo. Há aproximação entre cooperativas e políticos para a formulação de estratégias de intervenção. Mas estas estratégias precisam de tempo para serem assimiladas efetivamente.

Agora, com esse trabalho que está sendo feito de base, de cursos e de aperfeiçoamento, isso vai melhorar, mas é uma mudança que é de $180^{\circ}$, então ela não pode se fazer da noite para o dia, nem nada disso, tem que ser 
muito calmo, muito lento, muito devagar, para que haja essa assimilação (GESTOR DA COOPERATIVA C, 2013).

Por último, independentemente das glorias e absurdos, das positividades e negatividades envolvidas no trabalho da coleta seletiva, todos os gestores gostam do que fazem. Todos os gestores têm pulso firme no comando das cooperativas. Suas falas representam isso. Um deles (Gestor B) está temeroso quanto à possibilidade de não estar mais presente na cooperativa

Fico satisfeita quando emprego alguém; em tudo, participo de tudo. E eu entendo bastante e eles me entendem (GESTOR DA COOPERATIVA A, 2013).

E hoje em dia nós temos isso aqui, que Deus mandou, porque você só ocupa um lugar desses quando Deus te bota e Deus sabe que você vai tocar aquele serviço, que é tanta gente nessa comunidade. Porque não ficou no meu lugar? Eu falo... Eu digo, meu Deus, "Deus me livre dona fulana ficar de frente nessas coisas", o pessoal tem medo de tudo. Eu também tenho medo de tudo, mas eu confio muito em Deus. Eu sou muito medrosa. Eu não sou corajosa, eu confio em Deus. [...] Ai meu Deus. Eu vejo acabar tudo. Seu eu sair um dia, se você for vir aqui um dia, vocês vão ver.... cadê dona fulana? Tudo aqui eu sou.... A frente desse trabalho. No dia que eu não venho aqui, eu fico pensando, "ai meu Deus, como tá...". Quando eu chego aqui no outro dia, as mulheres fica "ai dona fulana, a senhora não tava ontem aqui, foi uma bagunça aqui no lixo". Porque ali eu fico organizando, "olha gente, tira essa parte, olha gente vamos tirar essa parte aqui, por que senão essa parte vai ficar velha aí, vai ficar [INAUDÍVEL]". Então não pode se dar [INAUDÍVEL], aqui não é o lixão de Gramacho, aqui é o lixão da cooperativa. Então tem pessoas que vêm aqui falar assim "dona fulana, a gente não sente cheiro de lixo aqui dentro da sua cooperativa, a gente chega por aí e tem lugar com cheiro de lixo". Eu digo "é que eu me preocupo... eu explico pra eles que não pode deixar o lixo ficar três dias". Quando... o caminhão chegou hoje, esse de hoje eles não vão limpar hoje, só vão limpar amanhã, vão terminar o anterior, depois que termina aquele anterior vão limpar aquele. E depois vai pra outro novo. Então é assim eu nunca deixo o material ficar velho. Porque o material pode ficar velho e mais tarde dar alguma... (GESTOR DA COOPERATIVA B, 2013).

Tô aqui... Junto com esse povo, que talvez não tem nem voz, nem muita chance, me identificando com eles, dando um pouquinho do meu dia, da minha vida, do meu carinho, da minha atenção, brigando com eles, fazendo com que eles reajam, e se sintam um pouco mais úteis e descubram qual é o verdadeiro valor e sinal pra eles. Então é isso como eu vejo (GESTOR DA COOPERATIVA C, 2013). 
Por fim, é inegável o amor que eles sentem pelo trabalho desenvolvido. Há uma comunhão em todos os sentidos, tanto nas relações sociais quanto nas relações profissionais. A cultura da partilha, tanto nas coisas boas e ruins é evidente.

É tudo, é minha vida, é aqui, é meus filhos, tem muita coisa aqui dentro, [INAUDÍVEL], o pessoal. Nossa, imagina como eu fico satisfeita quando abro a porta e dou emprego pra alguém. Tudo tem aqui, a vida nossa é aqui, é uma família. Porque a gente vive mais aqui do que em casa. Família nossa é aqui dentro. Os problemas, as coisas boas e coisas ruins. É tudo a gente. Mais fácil até passar daqui... Quando cheguei em casa, cheguei sem problema nenhum, porque já resolvemos tudo aqui. Problema pessoal, problema de tudo. É uma família mesmo (GESTOR DA COOPERATIVA A, 2013: 360).

Eu adoro, eu amo. Agradeço a Deus por todo esse trabalho. E hoje em dia eu tô agradecendo muito mais a Deus, por que... Como mudou. Mudou e vai mudar mais ainda, porque eu tenho fé em Deus que nosso presidente vai... agora na próxima eu vou falar com meu presidente lá em Minas. Ele já me conhece porque eu fico bem na frente. (GESTOR DA COPERATIVA B, 2013: 378).

\section{Considerações Finais}

Na observação empregada nas visitas às cooperativas, percebemos a comunhão existente. A partilha pelos valores de solidariedade em meio a precariedade das condições de trabalho e precarização do mesmo. As estórias contadas, a aproximação com os gestores e a possibilidade de entender que são relações sociais que pouco se assemelham a de uma empresa. As pessoas se identificam; sabem-se os nomes; há abertura para questionamento e sugestões; o ambiente é mais tranquilo (a não ser quando o caminhão chega trazendo materiais); ouvem-se as vozes das pessoas; e se anda de cabeça erguida, reconhecendo as feições dos rostos. A possibilidade de se visitar as cooperativas, escutar os gestores representa a possibilidade de, mais uma vez, dar-lhes vozes, dar-Ihes a confiança de que, mais uma vez, se tentará mudar a realidade de uma forma transformada positiva. As cooperativas trazem as perspectivas e limites, em paralelo com as políticas públicas, de se mudar ou de se adaptar a coleta seletiva no município do Rio de Janeiro. Temos as políticas, atores e Instituições. O desafio é o de organizar pessoas, interesses, vozes, problemas e soluções. 


\section{Referências Bibliográficas}

Abreu, Maria Aparecida Azevedo. (2010). “Educação: um novo patamar institucional". Revista Novos Estudos, v. 87.

BRASIL. Plano Nacional de Resíduos Sólidos (versão preliminar). Brasília, 2012. Disponível na Internet em: http://www.sinir.gov.br/web/guest/plano-nacionalde-residuos-solidos [Data de acesso: 8 fev. 2012].

Rocha, Décio., \& Deusdará, Bruno. (2005). Análise de Conteúdo e Análise do Discurso: aproximações e afastamentos na (re)construção de uma trajetória. Alea. Vol 7(2):305-322.

Rua, Maria das Graças. (2009). Políticas Públicas. Brasília: Capes (UAB).

Vergara, Sylvia. (2010). Métodos de pesquisa em administração. 4a edição. São Paulo: Atlas. 